\title{
TURKEY AND THE EUROPEAN UNION CONVERGING OR DRIFTING APART?
}

\author{
Halûk KABAALIOĞLU *
}

\section{Introduction}

The aim of this paper is not to go into the details of the historical background of Turkey's relations with other European countries or participation in various organisations. However, a few highlights may be appropriate as an introduction.

An English Quaker, William Penn, published a book in 1693 which was entitled "An Essay Toward the Present and Future Peace of Europe" where he proposed the gathering of a sovereign European "Diet" or "Imperial". Penn noted that there would be 90 seats in this "Common Assembly" and allocated them among the prospective member states: Germany 12, France and Spain 10, Italy 8, England 6, etc. Penn added that Turkey, if it wished, could join in this new organisation with 10 seats. What is important in this project is that it was made in the heyday of the Ottoman Empire by a Christian religious leader underlying the fact that a European organisation cannot be envisaged without the participation of Turkey. He may have been so disappointed with the subsequent events that he crossed the ocean and established the state of Pennsylvania. (On the other hand, some sources claim that Penn had a precondition for Turkish entry : Converting from Islam to Christianity. Although I have been unable to verify that claim, if that is true, then the Christian Democratic Parties of Europe (EPP), after their Brussels Summit in March 1997, rejecting Turkey's accession on grounds of religion followed up the same line.)

An Austrian aristocrat, Count Richard Coudenhove-Kalergi, in his book "Pan Europa" and in various articles published in the second half of 1920's, noted that Europe should proceed to establish a federation. While excluding the UK from his European project, CoudenhoveKalergi noted that if so wished, Turkey could join this European organisation.

* Professor of European Law; President, Turkish Universities Association of European Community Studies ; Member of the Executive Board of the Economic Development Foundation (IKV), Founding Director of EC Institute, Marmara Universty; Former President of European University of Lefke; Former Secretary General of Istanbul Chamber of Industry; currently while on a sabbatical in Brussels University, also associated with the Permanent Delegation of Turkey to the EC. [e-mail: institute1@superonline.com]. This article has been prepared as an academic discussion paper and reflects only the personal views of its author. 
When French Minister of Foreign Affairs, Mr. Aristide Briand, proposed the establishment of a European organisation in 1930, by European members of the League of Nations. It was officially proposed that Turkey must be invited to join the League of Nations so that she could take part in the proposed European organisation. A proposal to that effect was drafted by Spain and seconded by Greece.

After the second World War when the Council of Europe was established, one of the first resolutions of the Council of Ministers was to invite Turkey to this European organisation where Turkey became a member from its inception in 1949. We must also add that membership of the Council of Europe was quite restricted for the first three decades, as the number of democracies in Europe was somewhat limited. In fact, during the 1950s, 1960s and 1970s, the members of the Council of Europe were less than half of its members today. Spain and Portugal could join only at the end of the 1970s and Central and Eastern European countries started to join towards mid 1990s.

In addition to the Council of Europe, Turkey has been, most of the time, the founding member of many European organisations. Turkey joined the North Atlantic Treaty Organisation in 1952 three years after its establishment, but well before Germany for example, which joined in 1955. The role Turkey played in the south-eastern flank during the cold war period was certainly an important and substantial contribution when Russian missiles and Red Army troops were heavily deployed alongside the West German border not only in the DDR, but also in all the Warsaw Pact countries.

After the Messina Conference which started in 1955, the original six Member States of the European Coal and Steel Community, signed the Treaty establishing the European Economic Community on 25 March 1957 in Rome. It is interesting to note that some months after the signing of the Treaty of Rome, in another part of southern Europe, in Ankara, a new government was presenting its programme to the Grand National Assembly of Turkey on 11 November 1957, where the establishment of the European Economic Community was discussed in great detail. Indeed, Prime Minister Menderes referring to the "common market" and "economic initiatives in Europe" was bold enough to say that this new organisation was expected to lead to a "Political Union" in Europe and Turkey could not stay outside this new formation, as she was already a member of all the European Institutions, from the Council of Europe to the North Atlantic Treaty Organisation and OECD. In 1957, even before the entry into force of the Treaty establishing the 'European Economic Community, Prime Minister of Turkey, referring to this new initiative in his Government Program as the nucleus of the future "Political Union of Europe", concludes therefore that Turkey should be in this new organisation, not because it is an economic community, but because it will eventually lead to a "European Political Union" and since Turkey is a member of all the political, economic and defence organisations of Europe, it has to join this new formation.

It must be emphasised that the political vision of the Turkish statesmen in the second half of 1957, and their determination to take part in this new European venture (which for many uninterested observers of the time was purely an "economic integration" model based on a customs union) was in fact in line with the vision of Paul-Henri Spaak, Robert Schumann, Konrad Adenauer, de Gasperi, who were aiming for a political union in the future. 
It was precisely this political vision which prompted the Turkish government to apply to the Community on 31 July 1959, for the establishment of an Association. This is also particularly noteworthy as many other European countries stayed away from the historical venture of the original six and even established their rival organisation which clearly excluded any political co-operation, let alone union in the future, as it could easily be detected from its own name: European Free Trade Area ${ }^{1}$. The Government of Turkey by making a request for an association in July 1959, was actually acting in line with the Government Programme it presented to the Parliament in November 1957, which clearly underlined the political will of the Government to take part in the EEC, with an emphasis on the real reason why Turkey should join (that is, although this community sounds like a mere economic community, a common market, it will lead to a "political union.") In fact, Prime Minister Menderes was forming his third Government (Council of Ministers) since 1950. After the "White Revolution", that is the elections of 1950 when Mr. Ismet Inönü (who was elected as President after Kemal Atatürk's death in 1938, and served as President of the Republic until 1950) and his Republican People's Party suffered a big defeat and the Democrat Party of Mr. Adnan Menderes was voted in with more than 450 seats in the Parliament and opposition only around 50 seats. The second cabinet the Democrat Party formed was after the 1954 elections and the third in 1957 , after early general elections with a somewhat smaller majority compared to earlier election landslides.

The pioneers of European integration in Brussels, in the formative years of this venture were extremely pleased that Turkey, together with Greece, made their choice in line with the EEC and not EFTA. In fact, the response of the Commission was so swift that after receiving the Turkish application on the last day of July 1959, just before the month-long summer vacation, explanatory negotiations with the Turkish delegation started on 28 September 1959.

After the completion of a series of negotiations the Association Agreement was signed on 12 September 1963 in Ankara with a big ceremony held at the Grand National Assembly of Turkey with the full participation of Foreign Ministers of the six member States and the Commission President Prof. Dr. Walter Hallstein who declared that "with this Association Agreement Turkey has tied her destiny and future with the European Communities". President of the European Council, the Foreign Minister of the Netherlands, Mr. Joseph Luns also stated that "the Association Agreement was not an end but only a beginning". All the speakers from the Community, all of them being Ministers of Foreign Affairs of the original six underlined the understanding that this Association Agreement was going to lead Turkey to full membership in the Community. This was all in line with Turkey's European vocation, Kemal Atatürk's courageous and wide-ranging reforms starting with the declaration of the Republic of Turkey in 1923. All the members of the European Council spoke like the President of the Commission, Prof. Dr. W. Hallstein: "With this Association Agreement Turkey has tied her destiny and future with the European Communities". The subsequent developments and especially the fact that Turkey has been excluded from the list of countries for which "special accession procedure" has started after the Luxembourg Summit of 1997; the fact that financial co-operation has been blocked and turned into some symbolic amounts which brings doubts as whether the EC is actually fully aware of the magnitude and importance of the customs union; and that it can not succeed without full cooperation in all fields between 
Turkey and the European Union, the fact that "Greek membership of the EC upset the balance in the region which previous ministers carefully maintained" as framed by a top EU Commission diplomat; and the fact that "this imbalance seriously undermines Turkey's and West's strategic and economic interests in the region" must all be evaluated having Hallstein's remarks in mind: Turkey has tied her destiny and future to Europe.

It appears, the seriousness of the problem, the deep resentment that the Union has caused in Turkey, in the Turkish political system, in Turkish public opinion is not, still, really fully realised by the EU side. Brussels and Member States pretend like they are unaware of the seriousness of the situation. And what is alarming, every effort is being made to push these relations to a "dead-end" by pursuing a path in violation of the 1959-1960 Zurich and London Agreements, the founding Treaties of Cyprus and the basic safeguards of Turkish interests in Cyprus, and pretending that Cyprus can accede the EU before Turkey. Unless urgent and serious measures are taken, Turkey's relations with the EU can not carry this heavy blow.

The Turkey-EC Association has not been understood that well. Furthermore, in recent years we have witnessed efforts to neglect the most important aspects of this Association, the fundamentals of the relation was simply ignored. In fact, the Association may be facing attempts of derailment. Therefore, at the present time the most important measure must be to stop this derailment.

The next part of this paper will focus on the Association Agreement and Additional protocol and attempt to draw a picture of the "model" agreed.

Pre-accession and development aspects of the association will be underlined. The importance or sine qua non aspect of financial co-operation will be emphasised. While doing that, the economic realities of the customs union will be studied. This will bring us to the approach taken by the 15 Member States. As Ambassador Lake, the Representative of the European Commission in Turkey for seven years, puts it in his "End of Post Report", "is the EU going to restore the strategic balance in the region?" This imbalance "seriously undermines western strategic and economic interests in the region" according to Lake. The "southern sector" of the EU "remains politically and economically crippled". As the Cyprus problem has been pushed into the EU framework, in violation of the Treaties and the 1960 Constitution, some aspects of this issue will also be touched upon.

\section{Stock Taking}

In order to have a "stock taking" of Turkey-EU relations, we must examine the 1963 Association Agreement and determine what this Agreement (which is indeed "the Constitution" of our relations) provided for. Needless to say, without a comprehensive "stock taking" we cannot make down-to-earth evaluations for the "prospects" of this relationship. Therefore, we must start with the basic legal text, the 1963 Association Agreement. "Agreement Establishing an Association Between the European Economic Community and Turkey" signed on 12 September 1963 was adopted by the Council Decision of 23 December $1963^{2}$ and entered into force in December, 1964, after it was ratified not only by the Turkish Parliament (T.B.M.M., the Grand National Assembly of Turkey), but also by all the Member State Parliaments. 
What kind of a relation was envisaged in this Association Agreement?

What did it provide for ? A Commission publication entitled "Turkey-EEC Relations 1963$1977^{\prime 3}$, which appeared both in English and Turkish, defined the Turkish association as "a permanent, general and institutionalised bond for co-operation representing a participation by the third country in the objectives of the Communities" 4

The same Commission publication draws the attention of its readers to the special characteristics of this Agreement: "This Association formula is totally different from other Association Agreements the Community has entered into". What is so different with this "Association Agreement"? The answer is provided in the same publication: "In the case of Turkey, as for Greece, the association formula of Article 238 was used as a form of preaccession. Article 28 of Turkey's Association Agreement provides that the Contracting Parties will examine the possibility of Turkey's accession to the Community. Or to put it differently, association is considered as a preliminary to an eventual accession". Thus, it was referred to as "an association prior to accession" as well as "an association for the purposes of development".

Accordingly, we can characterise this Agreement in the following terms:

- Association Agreement with Turkey was used as a form of "pre-accession" agreement and aimed at the accession of the associate state to the Community.

- It was also an "association for the purposes of development".

These important characteristics of the Agreement is clearly stated in its Preamble. The Preamble is completely different from any other "association agreement" which may be a simple "trade and co-operation agreement". The Member States and Turkey signed this Agreement, according to its Preamble, "determined to establish ever closer bonds between Turkish people and the peoples brought together in the European Economic Community". A careful reader may say that he or she has seen the same terminology somewhere else. Indeed, the Preamble of the Treaty Establishing the European Community starts with the same provision: "determined to lay the ever closer Union among the peoples of Europe".

Why would the drafters of this Association Agreement take almost the exact terms of the Treaty of Rome ? The reason is simple: this is a "pre-accession association". Everything has been drafted in order to prepare Turkey for full membership. Therefore, the model they take for this Association Agreement, the aims, objectives and all the instruments and common policies are all adopted from the Treaty of Rome.

Below you have the texts of both Preambles which make an interesting reading. The European Court of Justice in Luxembourg and the Advocate Generals while analysing similar agreements, from time to time, refer to the aims, objectives and targets of the agreements and sometimes refer to the Preamble even though it may not constitute the legally binding portion of the Agreement. (Indeed, in Meryem Demirel v. Stadt Schwabisch Gmünd case, the Advocate General Darmon stated the following: "In this case it must be seen as part of an association agreement founded on the desire to 'establish ever closer bonds between the Turkish people and the peoples brought together in the European Economic Community with 


\begin{tabular}{|c|c|}
\hline $\begin{array}{c}\text { PREAMBLE OF THE } \\
\text { ASSOCIATION AGREEMENT }\end{array}$ & $\begin{array}{c}\text { PREAMBLE OF THE TREATY } \\
\text { OF ROME }\end{array}$ \\
\hline $\begin{array}{l}\text { " Determined to establish ever-closer } \\
\text { bonds between the Turkish people and the } \\
\text { peoples brought together in the European } \\
\text { Economic Community } \\
\text { " Resolved to ensure a continuous } \\
\text { improvement in living conditions in Turkey } \\
\text { and in the European Economic Community } \\
\text { through accelerated economic progress } \\
\text { and harmonious expansion of trade, and to } \\
\text { reduce the disparity between the Turkish } \\
\text { economy and the economies of the } \\
\text { member States of the Community; }\end{array}$ & $\begin{array}{l}\text { * Resolved to ensure the economic } \\
\text { and social progress of their countries by } \\
\text { common action to eliminate the barriers } \\
\text { which divide Europe; } \\
\text { Affirming as the essential objective of } \\
\text { their efforts the constant improvements of } \\
\text { the living and working conditions of their } \\
\text { peoples; }\end{array}$ \\
\hline $\begin{array}{l}\text { * Mindful both of the special problems } \\
\text { presented by the development of the } \\
\text { Turkish economy and of the need to grant } \\
\text { economic aid to Turkey during a given } \\
\text { period; }\end{array}$ & $\begin{array}{l}\text { * Recognising that the removal of } \\
\text { existing obstacles calls for concerted } \\
\text { action in order to guarantee steady } \\
\text { expansion, balanced trade and fair } \\
\text { competition; }\end{array}$ \\
\hline $\begin{array}{l}\text { * Recognising the support given by } \\
\text { the European Economic Community to the } \\
\text { efforts of the Turkish people to improve } \\
\text { their standard of living will facilitate the } \\
\text { accession of Turkey to the Community at a } \\
\text { later date; }\end{array}$ & $\begin{array}{l}\text { * Anxious to strengthen the unity of } \\
\text { their economies and to ensure their } \\
\text { harmonious development by reducing the } \\
\text { difference existing between the various } \\
\text { regions of and the backwardness of less- } \\
\text { favoured regions; }\end{array}$ \\
\hline & $\begin{array}{l}\text { Desiring to contribute, by means of } \\
\text { a common commercial policy, to the } \\
\text { progressive abolition of restrictions on } \\
\text { international trade }\end{array}$ \\
\hline $\begin{array}{l}\text { * Resolved to preserve and } \\
\text { strengthen peace and liberty by joint } \\
\text { pursuit of the ideals underlying the treaty } \\
\text { establishing the European Economic } \\
\text { Community. }\end{array}$ & $\begin{array}{l}\text { * Resolved by thus pooling their } \\
\text { resources to preserve and strengthen } \\
\text { peace and liberty, and calling upon the } \\
\text { other peoples of Europe who share their } \\
\text { ideal to join in their effort. }\end{array}$ \\
\hline
\end{tabular}


a view to the subsequent accession of Turkey to the Community. When such a convention looks towards a further accession, the Community must of necessity hold the most extensive powers to conclude agreements with non member countries in order to cover all the fields of activity contemplated by the EEC Treaty", 1987 ECR 3719). Turkish Association was similar to the Greek Association Agreement.

The Turkish Association Agreement does not only borrow a few sentences from the preamble of the Treaty of Rome, but goes much further than that. As Turkey is going to be a full member, the model the drafters adopted in this Association Agreement, naturally was the Treaty of Rome (the Treaty Establishing the European Economic Community). We look at the Treaty of Rome, especially Art. 9 thereof, which declares that "the Community shall be based upon a customs union which shall cover all trade in goods". Thus, the Association Agreement provides the same thing: "the final stage shall be based on customs union" (Art.5). Just like the Treaty of Rome, according to which the customs union was to be completed in 12 years time after three transitional periods, Turkish Association Agreement provided a "transitional stage" during which Turkey and the EC were to "establish progressively a customs union". Thus, the draiters of the Association Agreement between Turkey and the EC, just like the founding fathers of the EC, based an important aspect of the relations on a customs union.

Some commentators, newspaper editors and even "leading experts", sometimes speak of "signing an agreement in 1995 for establishing the Customs Union" as if a new Agreement was signed. This is not correct. The decision concerning the establishment of a customs union between Turkey and the EC was taken in 1963 with the Association Agreement. The time table for its implementation was provided in the Additional Protocol of 1970. In 1995 it was only an Association Council Decision, which was taken for the implementation of the Customs Union as provided in 1963 and 1970 Agreements. In fact, as it will be explained below in detail, the timetable set in this Additional Protocol, a period of 22 years, which commenced in 1973 with the entry into force, ended in 1995, thus the Customs Union was completed in accordance with these provisions Therefore, it was not a "new agreement", it simply was a "Decision" of the Association Council, declaring that the transitionary stage is completed and the "final stage" before full membership, which is based on a customs union, has commenced.

Although the customs union was an important aspect of the association (which provided not only the free movement of goods between Turkey and the EC, but also the adoption of the Common Customs Tariff (CCT) and Common Commercial Policy of the Community by Turkey), it was not only the free movement of goods, which was adopted from the Treaty. As this is pre-accession association, the model included all the aspects of the Treaty of Rome establishing the Community, not only free movement of goods, but also free movement of workers, free movement of services and free movement of capital, logether with the freedom of establishment, and common policies of the Community were in the 1963 Association Agreement and the timetables, and the calendars for their implementation were provided in the 1970 Additional Protocol. 
As stated out above, for all these free movements, the model adopted was the Treaty of Rome. The Association Agreement providing the free movement of workers underlined that while achieving this freedom "the Contracting Parties agree to be guided by Articles 48,49 and 50 of the Treaty establishing the Community for the purpose of progressively securing freedom of movement for workers between them". Likewise, for the freedom of establishment "The Contracting Parties agree to be guided by Articles 52 to 56 and Article 58 of the Treaty establishing the Community for the purpose of abolishing restrictions on freedom of establishment between them". The same applied for the freedom to provide services: "The Contracting Parties agree to be guided by Articles 55, 56 and 58 to 65 of the Treaty establishing the Community for the purpose of abolishing restrictions on freedom to provide services between them".

The following "outline" of the Association Agreement, together with the Additional Protocol, may help the reader to understand the overall comprehensive nature of this Agreement, its fundamental raison d'être of being a pre-accession agreement to prepare an associate country to full membership. Thus, it is not "customs union" for the sake of establishing a customs union, the whole framework is based on the Treaty of Rome and it is not only free movement of goods (customs union) but all the four basic freedoms and all the common policies of the Community are included therein, in order to prepare the country for accession.

\section{Association Agreement of 1963}

* Pre-accession Agreement

* Agreement to prepare for full membership: Association for the purposes of development

Columns on which the association is built:

Free Movement of Goods : Customs Union. Art. 10. Definition of the customs union and basic principles same as Treaty of Rome.

Free Movement of Workers: Art. 12. Refers to the Treaty of Rome, Articles 48,49 and 50.

Free Movement of Services: Art. 14. Refers to the Treaty of Rome, Articles 55,56 and 58.

Free Movement of Capital: Art. 19-20 of the Association Agreement.

Freedom of Establishment:

Art. 13. Refers to Articles 52 to All the principles laid down in the Treaty of Rome (Title 5 of Part III)

56 and 58 of the Treaty. concerning these issues must be made applicable in their relations within the association

Common policies:

Agriculture: Art. 11. Association will extend to agriculture.

Transport: Art.15. Transport provisions of the Treaty of Rome shall be extended to Turkey.

Competition (Art.16)

Taxation

Approximation of laws

Discrimination on Grounds of Nationality: 
Prohibited by Art. 9 in line with Art. 7 of the Treaty of Rome

Duty to take all appropriate measures, to ensure the fulfilment of obligations arising from the Agreement (Art.7)

Duty to refrain from any measures to jeopardise the objectives (Art.7/2)

Decision making: Association Council

Association Council Decisions: Have direct applicability and direct effect, ECJ Judgement, Sevince v. Staatsecretaris van Justitie, Case C.192/89 (1990) ECRJ. 3461; 1962 CMLR 57 and subsequent judgements.

Wide powers for the Association Council in Association Agreement Art. 22/3 - Similar to Art. 235 of the Treaty of Rome

"The Council of Association shall adopt decisions where, in the course of implementation of the Association arrangements, attainment of an objective of this Agreement calls for joint action by the Contracting Parties, but the requisite powers are not granted in this Agreement.

- Accession (Art. 28):

As soon as the operation of this Agreement has advanced far enough to justify envisaging full acceptance by Turkey of the obligations arising out of the Treaty establishing the Community, the Contracting Parties shall examine the possibility of the accession of Turkey to the Community.

\section{Additional Protocol Annexed to the Agreement Establishing an Association Between the EEC and Turkey 5}

23 November 1970

- Starts the transitional stage:

Association Agreement of 1963 (Art.2/3): Association shall compromise:
a) a Preparatory stage
b) a Transitional stage
c) a Final stage

Additional Protocol: conditions have been established for passing from the preparatory stage to the transitional stage (1970)

- Timetables: Protocol provides the timetable for the implementation of the provisions of the Association Agreement (four basic free movements) and the conditions.

- Customs Union:

* Goods in free circulation (Art.2-6)

\section{Customs Union}

_ Elimination of customs duties between the Community and Turkey (Art.7-16)

*Adoption by Turkey of the Common Customs Tariff (Art.17-20)

_ Elimination of Quantitative Restrictions Between the Contracting Parties (Art.21-30)

"Turkey shall progressively abolish, over a period of twenty-two years after the entry into force of this Protocol, the basic duties". Art.11/1 (Entry into force: $1973+22$ years = 1995 which is the date of the 
entry into force of the customs union).

* "Turkey shall, ... align its customs tariff over a period of twenty-two years" (Art.18)

* The Turkish Customs Tariff shall be aligned on the Common Customs Tariff during the transitional stage. The CCT shall be applied in its entirety by 1995. (Art.17/4)

* Elimination of Quantitative Restrictions Between the Contracting Parties (Art.21-30)

* Agriculture (Art.32-35)

- Movement of Persons and Services:

Just like the provisions for the free movement of goods leading to a customs union was provided in the Association Agreement and implementation timetable/calendar was decided in the Additional Protocol, for free movement of workers the substantive provisions was decided in the Association Agreement (1963) and timetable was provided in the Additional Protocol (1970).

- Art.12 of the Association Agreement: "The Contracting Parties agree to be guided by Articles 48,49 and 50 of the Treaty establishing the Community for the purpose of progressively securing freedom of movement for workers between them". Thus, the substance of this item is provided in the Treaty of Rome. Since this is a pre-accession association, it is only natural that, just like for free movement of goods leading to customs union, free movernent of workers in relation with Turkey would be based on the relevant provisions of the Treaty of Rome.

-Timetable for the free movement of workers (Additional Protocol art. 36) :"Freedom of movement for workers between Member States of the Community and Turkey shall be secured by progressive stages in accordance with the principles set out in Article 12 of the twelfth and twentysecond year after entry into force of that Agreement".

Entry into force of the Association Agreement: 1964

$$
\begin{array}{r}
-1964+12=1976 \\
-1964+22=1986
\end{array}
$$

Thus, according to Art. 36 of the Additional protocol, free movement of workers should be progressively secured between 1976 and 1986. The final date for securing free movement of workers, (similar to Art.48 of the Treaty) was 1986.

Accordingly, when Turkey was gradually reducing her customs duties on Community industrial products (list A in 12 years, list B in 22 years which means 1986 and 1996) free movement of workers was to be implemented gradually starting in 1976 and completing this free movement by the end of 1986 as provided in the Protocol 6 Whereas the dates provided for free movement of goods were observed with the completion of the customs union at the end of 1995; the dates provided for free movement of workers passed and no Association Council Decision was taken for their implementation. Thus, an equally important column of the Association could not be constructed. A close observer of Turkey-EC relations, in a lengthy analysis of the balance of rights and obligations of the two Parties, after underlining the importance of the release of the fourth Financial Protocol, which has been blocked since 1980, pointed out that there was a need to make "an offer to a direct follow-up by a new Financial Protocol or another measure which would contribute to the compensation for the negative economic consequences caused by the denial of freedom of movement" for workers.

\section{- Conditions of work and remuneration: Art.37}

"Community shall not discriminate on grounds of nationality between Turkish workers and workers 
who are nationals of Member States".

- Social Security measures for workers of Turkish nationality and their families (Art.39)

Encouraging the exchange of young workers (Art.40): Guided by the measures adopted by

Member States in implementation of Art.50 of the Treaty of Rome.

- Right of establishment (Art.41): Guided by Articles 55,56 and 58 to 65 of the Treaty of Rome.

Timetable to be determined by the Association Council

- Standstill clause on freedom of establishment and freedom to provide services

"The Contracting Parties shall refrain from introducing between themselves any new restrictions on the freedom of establishment and the freedom to provide services" Art.41/1.

This provision is clear, unconditional and does not require any implementation measure, therefore it has direct effect. Thus "any new restriction on the freedom of establishment and freedom to provide services", after entry into force of this provision, in 1973 is liable to be condemned by the Court of Justice.

- Transport (Art.42): Transport provisions of the Treaty of Rome shall extend to Turkey.

- Competition (Art.43): Community Competition Law (conditions and rules for the application of the principles laid down in Art.85,86,90 and 92 of the Treaty) shall be adopted by Turkey.

- Taxation (Art.44-45): Treaty provisions Art.95 and following are included.

- Approximation of laws (Art.48): Laws, regulations or administrative provisions in respect of fields which are not covered by the Additional Protocol but have a direct bearing on the functioning of the Association must also be harmonised.

-Economic policy (Art.49): Co-ordination of economic policies

-Commercial policy (Art.53) ; Public undertakings (Art.57) ; Safeguard measures (Art.60).

The Ministers on the Community who signed this Protocol were Pierre Harmel, Walter Schell, Maurice Schumann, M. Pedini, Gaston Thorn, Joseph Luns and Franco Malfatti, Commission President, and I.S. Caglayangil for Turkey. Few lines from the Joint Press Communiqué published on 23 November 1970 after the ceremonies for signature may be illustrative as to its aims: "Avant de procéder à la signature des différents actes, des allocutions ont été prononcées respectivement par le Président du Conseil, le Président de la Commission et le Ministre des Affaires étrangères de la République de Turquie. Tous les orateurs ont tenu à souligner l'importance que la signature de ces actes revêtait tant pour la Communauté que pour la Turquie. Ils marquent, en effet, le début d'une étape décisive cers l'adhésion ultérieure à part entière de la Turquie à la Communauté européenne qui constitue 
la finalité politique de l'Accord d'Ankara, étape durant laquelle le processus d'intégration économique des deux partenaires va se réaliser progressivement.La réussite des négociations pour le passage à la phase transitoire confirme à la fois la volonté de la Communauté et de la Turquie de poursuivre et d'intensifier leur coopération en vue d'atteindre cet objectif final ainsi que le bon fonctionnement sur les plans commercial et financier du régime de la phase préparatoire en vigueur depuis décembre 1964, qui a permis aux Parties d'envisager le passage à cette nouvelle phase de l'Association. La Communauté et la Turquie ont toutefois été conscientes que, pour une économie en développement, l'entrée dans un processus d'union douanière avec des pays hautement industrialisés ne peut être réalisée harmonieusement que s'il est pleinement tenu compte, dans la définition des modalités de ce processus, des nécessités du développement de certe économie. Les Parties se sont assigné cet objectif pour l'élaboration du protocole additionnel dont le contenu, souple et évolutit, a été conçu de manière à contribuer efficacement aux efforts déployés par la Turquie dans le domaine du développement économique. C'est dans le même esprit qu'a été conclu un nouveau Protocole financier qui met à la disposition de l'économie turque des prêts à des conditions spéciales. II est rappelé par ailleurs que le Protocole additionnel est l'instrument juridique qui définit les modalités de mise en oeuvre de la phase transitoire mais que les éléments essentiels de celle-ci ont déjà été prévus par l'Accord d'Ankara lui-même "7

The above outlines, demonstrating the comprehensive nature of the Agreements signed between Turkey and the EC, clearly establish that the target is not only a customs union, but the preparation of the country into full membership. Otherwise, it would not be necessary to include all of the four basic freedoms, all common policies of the EC as early as 1963. At the time when this Agreement was signed, together with the Greek Association Agreement, they were considered as very unique "integration models."

The following comments by a Commission adviser, concerning the "principal objective" of the Association, seem to neglect the pre-accession nature of the Agreement: "The EU's formal relationship with Turkey derives from the 1963 Association Agreement with the EEC. Known as the Ankara Agreement, this document held out the possibility of future accession to the EEC. Its principal objective, however, was the establishment of a customs union, the transitional stages of which were provided for in the 1970 Additional Protocol" 8 . The establishment of a customs union was and is not the "principal objective" of the Association Agreement. The "principal objective" is, of course, Turkey's accession to the Union. Why would Turkey wish to establish a customs union with the EC on its own if there was no membership? Why should Turkey accept decisions taken elsewhere for her commercial policy as she is not in the decision making bodies? Why should Turkey adopt the Common Customs tariff of the EU and give up her own competence and accept the decisions taken in Brussels in this very importany matter? All these are accepted, provided that it will lead to full membership, in not too distant future. Othenwise, there is no sense in establishing a customs union. Thus, the customs union can only be for a transitional phase which would lead to full membership. This is what the Agreement cleanly provides for. Its objective is not having a customs union for the sake of customs union. Customs union has been completed with the full understanding that it will lead to full membership. Indeed, when we look at history we see customs unions lead to further integration like Zollverein, for example, and they cannot continue on their own indefinitely. 
Thus, "progressive integration" is the model on which this Association is constructed. As Molle explains the progressive integration "is based principally on an analysis of the factors underlying the dynamics of integration, the outcome of which is that under conditions prevaliling in western Europe, a free trade area and a customs union are unstable forms of co-operation, which can function only if progressing continuously towards further integration. ${ }^{9}$ When the process stagnates, forces opposed to the Union's "rule of the game" may gain weight and combine with others to become a serious threat to the freedoms achieved. Disintegration could then be prevented only by further integration" . We should retum to this subject while discussing Luxembourg.

Mr. Emile Noël, who was born in istanbul and who served as the first Secretary General of the Commission for almost three decades, has said that "an Association on the basis of the customs union, when fully implemented, includes a lot of administrative, economic and political constraints, when the associated member does not take part in the decision-making process, except on a consultative basis. Such a position can be acceptable for a short time before full membership. It cannot be sustainable if membership is denied". ${ }^{10}$

\section{ASSOCIATION AGREEMENT}

\section{Preamble:}

Recognising that the support given by the European Economic Community to the efforts of the Turkish people to improve their standard of living will facilitate the accession of Turkey to the Community at a later date

Mindful both of the special problems presented by the development of the Turkish economy and of the need to grant economic aid to Turkey during a given period

Resolved to ensure a continuous improvement in living conditions in Turkey and in the EEC through accelerated economic progress and harmonious expansion of trade, and to reduce the disparity between the Turkish economy and the economies of member States

Determined to establish ever-closer bonds between the Turkish people and the peoples brought together in the EEC.

\section{Preparation for full membership:}

"Turkey shall, with the aid from the Community, strengthen its economy so as to enable it to fultil the obligations which will devolve upon it during the transitional and final stages". (Art.3/1)

Take full account of the need to ensure an accelerated development of the Turkish economy and to improve the level of employment and the living conditions of the Turkish people:

While taking all these into account, promote the continuous and balanced strengthening of trade and economic relations between Turkey and the EC (Art.2)

\section{FINANCIAL PROTOCOL}

Preamble:

Desiring to promote the accelerated development of the Turkish economy in furtherance of the objectives of the Agreement of Association (1964)

Anxious to promote an accelerated development of the Turkish economy in order to facilitate the pursuit of the objectives of the Agreement (1970)

\section{Investment projects:}

should be submitted to the European investment bank for financing. These projects financed by the $\mathrm{E} B \mathrm{~B}$

- will serve to increase the productivity of the Turkish economy and

- further the objectives of the Agreement of Association

Loans on special terms (Art.4):

- Reduced rates of interest,

- Extended Repayment periods,

- Interest free periods,

- Any other special repayment terms which may facilitate the servicing of such loans by Turkey. 


\section{Development Aspects of the Association}

Now, we can focus on the second important characteristic of the Association Agreement. First, being the pre-accession, second is the "development aspect" of the Association. The Preambles of the Association Agreement and the Additional Protocol underlines the importance given to the development aspects.

The First Financial protocol signed together with the Association Agreement on 12 September, 1963 provided for loans "up to a total of 175 million units of account which may be committed in the five years following the entry into force of this Agreement" (Art.2). The Agreement entered into force in December 1964. The amount allocated for the First Financial protocol, 175 million units of account, might seem like a negligible amount but if one recalls that the annual exports of Turkey in 1964 were only 400 million dollars, the financial support provided to prepare Turkey for membership constituted a substantial support for investments especially in infrastructure projects.

The second Financial Protocol was signed on 23 November, 1970, the same day when the Additional Protocol was concluded. Article 1 of the Financial Protocol noted that "within the framework of the Association between the European Economic Community and Turkey, the Community shall supplement Turkey's own endeavours by qarticipating, in measures to promote the development of that country". According to the Preamble, both sides were "anxious to promote an accelerated development of the Turkish economy in order to facilitate the pursuit of the objectives of the Agreement establishing an Association". The amount allocated between 1973 and 1976 was "up to an aggregate amount of 195 million units of account" (Art.3/2).

The Third Financial protocol signed on 2 May, 1977, which was "aiming to help increase the productivity of the Turkish economy" and in particular, aiming "to provide Turkey with a better economic infrastructure, higher agricultural output and modern, efficiently-run undertakings in the industrial and service sectors whether they are publicly or privately managed", noted that the main objective was to "further the realisation of the objectives of the Association Agreement" Art.2/2 (b).

The amount allocated for that purpose in 1977 was an "aggregate amount of 310 million European units of account" which was to be committed as 90 million EUA in the form of loans from the European Investment Bank and 220 million EUA in the form of loans on special terms granted by the Bank acting on instructions from the Community. Art.2/1 (a)(b). We must also add that on 19 September 1980, a few months before Greek accession, the Association Council, "having noted the Community's offer to grant Turkey exceptional aid totalling 75 million EUA", decided for the implementation of this "exceptional aid" (Decision 2/80).

The Fourth Financial protocol negotiated in 1980 was for an amount of 600 million ECU which represented an amount around one third of Turkey's annual exports. However, with the accession of Greece to the European Community, as of 1 January 1981, almost all aspects of the financial co-operation with Turkey have been blocked. The Fourth protocol was for a fiveyear period and normally there should be two more financial protocols, each for a period of five years up to 1996 when the third phase of the Association before accession commenced based on customs union. 
Because of Greek objections, the present phase of our Association which is based on customs union, faces serious threats to its existence, as it is unthinkable that a customs union between an industrial giant like the EC and Turkey can function without substantial support from the other side. As pointed out by the Community declaration on financial cooperation on 5 March 1995, a comprehensive, effective, long term and substantial financial support from the Community is a sine qua non of the customs union. In order to understand the importance of this question, we must study the regional and economic effects of the Customs Union. In the $\mathrm{EC}$, from the very beginning, during the formative years, it was realised that there were structural imbalances between members of the customs union. Therefore, a number of instruments were devised to correct such imbalances. "Structural Fund", "Regional Fund", "Cohesion Fund" etc.. So, what are the regional and economic effects of customs unions?

\section{Regional and economic effects of the Customs Union 11}

Economists tell us that the liberalisation of factor movements may entail the gravitation of productive factors from slow-growth areas, and this may, in the short-term, cause economic imbalances and inequality which would naturally be unacceptable to Member States. Accordingly, the creation of a customs union profoundly affects the labour and capital markets in the countries concerned, and the integration of production factor markets affects the production of goods and thus trade.

As far as standard neo-classical economic theory is concerned, it is of no real consequence why regional disparities emerge, since there are mechanisms in an economy which will ensure that they will prove to be only a temporary phenomenon. Tomkins and Twomey argue that "cumulative causation theories" provide a strong theoretical rationale for widening regional prosperity. The basis of these theories lies in the recognition of the fact that because of the impact of differing levels of productivity or the existence of internal and external economies of scale, it is perfectly feasible that economic benefits begin to accumulate in particular regions of an economy and become self-perpetuating. In such circumstances, market forces may actually come to reinforce this development and contribute to unbalanced regional growth. 12

It is clear that once the process of economic integration is in progress, it is likely that already existing problems of regional disparities will intensify. The productivity differentials will continue to exist and they will favour the technologically advanced firms of developed areas within the economic union.

Another important factor to be taken into consideration is this: economic integration may encourage concentration of new industry and relocation of existing industry in certain areas of the union which give superior infrastructure, lower transport costs and availability of skilled labour. Thus, with the enlargement of the market and enhanced competition, the most efficient enterprises will expand by the integration process, while the less efficient will be driven out of the market. Consequently, the economic activity at the periphery of the economic union will be affected negatively and disproportionately from the effects of integration as the enterprises at the periphery are on the whole less efficient, with lower productivity than those at the developed centre. Hitiris, in his book, "European Community Economics" submits that "in 
addition to these problems, there is always the possibility that common policies undertaken for the realisation of integration objectives may have profound and sometimes unforeseen regional effects". ${ }^{13}$ Therefore, it is clear that, as a consequence of these reasons, the rates of growth in the developed centres will be higher than those in the less-developed regions of the union.

On the one hand, the economic theories point out the advantages of primary forms of integration, namely of the goods markets and markets of production factors and argue that all partners may profit from the establishment of a customs union. Furthermore, the economic theories also underline that "the profit of integrated product markets is enhanced if the internal movement of the production factors, that is to say movement of labour and capital, is liberalised. To let markets function properly, a certain level of positive integration is needed". (Whereas, in the Turkish case free movement of other production factors, labour and services are although provided in the Agreement are so far not implemented).

Economists and politicians act upon the following assumption: competitive markets (efficiency) generate considerable inequality. Government and other institutions are then required to reduce this inequality by redistribution, even if it means some loss of efficiency. 14

The European Community was created as a common market. The objective was to step up efficiency and stimulate economic growth by integrating the markets of goods and economic factors. The Association Agreement between Turkey and the EC also provides the integration of not only the markets of goods, but also the markets for all the productive factors. That the ensuing structural changes in the EC implied some unacceptable consequences for certain sectors of the society was expected (like relocation of economic activities, changing composition of sectoral activity etc..). The most vulnerable groups were concentrated in particular regions of the customs union. In short, regional problems are the disparities in the levels of income, in rates of economic growth of output and employment, and, in general, in the levels of economic inequality between the geographic regions. Free competition does not tend to equalise factor returns across regions and therefore regional differences in economic development remain an important problem. Thus, market forces cannot be relied upon to produce the necessary degrees of interregional balance in economic growth. Hence, areas that were considered relatively prosperous before integration may turn into backward regions of the union. Therefore, the costs and benefits of integration must be properly shared between the member countries and the regions of the economic union as a whole. To this end the EC developed a number of instruments and policies which should be extended to Turkey, being part of the same customs union. Indeed, the Community recognised that the problem of regional disparities between the richest and the poorest areas threatened to disrupt the convergence of economic performance inside the EC and to delay the progress towards integration. Various Community funds and common policies had been designed to function with regional problems among their objectives. These funds finance regional projects for modernisation of the industry, investment for job creation, and training and retraining schemes in problem areas. ${ }^{15}$ 
The Community decided that assistance will be provided where the GDP is below the national average or where there is dependence on agriculture or on a declining industry. Community regional funds are used in areas where there is a high rate of unemployment or net migration. Where Community policies, in particular free trade, have an adverse effect, the Community Structural Funds will enter the picture.

"Completion of the single internal market", according to a Commission paper, "renders inevitable that resources both of people and materials, and capital and investment, flow into areas of greatest economic advantage". Increasing openness of product and factor markets will generate gains, but it is not certain that they will be distributed equally among the regions of the Community. Therefore, it was admitted that the integration process may have adverse sectoral and regional effects on the problem regions. As a result, the Single European Act provided important increases in the funds allocated for regional development with particular emphasis on concentrating resources in the regions with per capita GDP of less than $75 \%$ of the Community average. These funds were from the European Regional Development Fund (ERDF), European Social Fund (ESF), Guidance Section of the European Agricultural Guidance and Guarantee Fund (EAGGF), etc.

Thus, all of Portugal, Ireland and Greece, parts of Spain, Italy and Eastern Germany, and the French overseas departments are listed as "first priority areas" because of their structural backwardness. This entitles them to funding of up to $75 \%$ from the Community Funds which were doubled by 1992, increasing their share of the overall Community budget from 18 to $28 \%$. Indeed, in February 1988 a decision was taken for the doubling in real terms of the resources of the three Funds in the subsequent five years.

The link established between the internal market and the doubling of resources ${ }^{16}$ through Structural Funds also meant an implicit recognition of the danger that the weaker regions of the Community could end up as net losers from further market integration. For the five-year period 1989-93, a total of ECU 60.3 billion (in 1989 prices) was committed, to be spent through the three Structural Funds.

It may be of interest to students of Turkey-EC Relations that, by 1992, annual transfers through the Structural Funds represented 3.5, 2.9, and 2.3\% of GDP for Portugal, Greece and Ireland respectively ${ }^{17}$. It must also be noted that the Commission called for a "further substantial increase" in the overall resources of the Structural Funds, which raised expenditure to approximately $33.5 \%$ of the EC budget in 1997 , compared with $27 \%$ in 1992.

On this matter the Agreement on the European Economic Area (EEA) constitutes an important model. One of the demands of the less-developed EC Member States in the EEA negotiations was that EFTA should assist in the development and structural adjustment of the poorest Community regions. (This was partly achieved through improved market access for certain agricultural products particularly important to the economies of these countries. Parallel to the EEA Agreement, a number of EFTA countries concluded bilateral agreements with the EC granting tariff and other concessions in the field of agriculture.) The main solution was, however, a system of financial assistance provided by EFTA States. The financial mechanism was based on two different elements: grants and interest subsidies provided in 
connection with loans granted by the European Investment Bank. Among projects submitted by undertakings, special consideration was to be given to small and medium-sized enterprises. It was an interesting model as these EFTA countries were not becoming part of the customs union but were going to benefit from the free trade agreement. The lessdeveloped Members States of the EC requested these grants as a price for the opening of their markets to EFTA countries (Article 115 to 117 and Protocol 38). ${ }^{18}$

With the customs union Turkey completely opened her markets to a much larger group of countries than small EFTA States. The EU constitutes at least a 20 times larger economic power compared with relevant EFTA countries at the time.

The Commission Opinion on Turkey's application for membership observed the following: "Progressive completion of the customs union will give the Community the opportunity to associate Turkey more closely within the operation of the single market, while taking into account the constraints imposed by the economic disparities between Turkey and the Community. This requires a strengthening of the machinery for agreeing concerted economic and social policies between the Turkish Government and the Community institutions" 19

As pointed above, the economic analysis discussed above, covers the conditions where all production factors, including, goods, labour, services and capital are in free circulation and the countries involved enjoy the advantages of being a Member State in terms of political and economic stability. Whereas, in Turkish case, only free movement of goods is achieved through the customs union, free movement of workers and services have not been implemented, in spite of the fact that a definite time-table for labour was provided in the 1970 Protocol paralel to the provisions of customs union. Furthermore, since Turkey is not a Member of the Union yet, the advantages of membership, vis-a-vis prospective foreign investors, advantageous credit facilities etc. can not be realized. Therefore, compared to those Member States which receive financial support, the disadvantages Turkey faces are wider, as one of the logical components of the Agreement, the other "supporting column" of the association is not yet implemented and the membership perspective brutally push to an uniorseeable distant future after the Luxembourg Summit which may partially explain why much expected rise in foreign investments did not materialize. Taking into consideration all the above referred factors, together with the "development" characteristic of the association, the European Community made a solemn declaration concerning the financial cooperation during the Association Council meeting where the Decision on Customs Union was taken on 6 March 1995.

\section{Community Undertaking Concerning Financial Support}

The Community Declaration Concerning Financial Cooperation was made during the Association Council meeting where the Decision 1/95 concerning the customs union was taken. In fact, the text of the Declaration was distributed weeks before the meeting in its draft form , together with the text of the Decision $1 / 95$ in order to demonstrate that it constituted part and parcel of the customs union decision. The draft of the declaration also made clear that it was "to be entered into the minutes of the EC-Turkey Association Council (6.3.1995)". 
The Community Declaration makes it clear that "in order to adapt its industrial sector to the new competitive situation created by the Customs Union and improve its infrastructure linkage with the European Union (road transport, ports, airports, railways, telecommunications and electricity),as well as to reduce the difference between its economy and that of the Community, Turkey will need substantial financial resources, in particular long-term loans and technical assistance".

This is followed by a firm commitment, without any "if", "but" or "when" proviso, concerning the financial cooperation with definite dates : "To this end, the Community will resume its financial cooperation with Turkey before the entry into force of the Customs Union and decide in the first half of 1995 on detailed arrangements for it".

The Declaration also made clear that financial cooperation was based on the following elements :

-"Substantial budgetary resources" made available for cooperation with Turkey over a five-year period starting in 1996. In the footnote, it was pointed out "for the record" that the "substantial budgetary resources" referred in the text was a mere ECU 375 million. As this amount is not really that "substantial", one may wonder whether this was an annual commitment,however a careful reading indicates that the intention was for a five year period.

- "Continued access to funds (EIB loans) available under the 1992-1996 Mediterranean policy for the financing of infrastructure projects in new the fields of environment, energy, transport and telecommunications". Here the expected amount is referred to as ECU 300 to 400 million, depending on the quality of the projects presented by Turkey.

- "Additional EIB loans over a five-year period starting in 1996, in order to improve the competitiveness of the Turkish economy following the entry into force of the Customs Union"

- "Funding facilities (budgetary resources as well as EIB loans), which the Community will make available, as from 1996, for all Mediterranean countries",

- "At Turkey's request and in cases of special need, the Community, in coordination with international financial institutions and in the light of all the funds available, could examine the possibility of granting exceptional additional medium-term macro-economic financial assistance linked to the execution of IMF-approved programmes".

When the total of these items were calculated, a sum of nearly 3 billion US dollars were involved. Taking into consideration the magnitude of the customs union, the amount allocated under financial cooperation was not anywhere near the support made available to Member States. During the public debates and discussions which took place in Turkey, the supporters of the customs union, admitting that the amounts declared were not in line with the needs of the country for adjustment and adaptation to the new competitive conditions, argued that customs union was such a project that when any additional need arise, in compliance with the solidarity principle, other support and cooperation mechanisms would be forthcoming.

Unfortunately, since the first half of the 1995 when the Community support programmes were to be introduced, this aspect of the customs union which is an indispensable part of the 
whole project could not be implemeneted. Ambassador Michael Lake who represented the European Commission in Ankara for seven years explains the situation in the following words: "The promised EU financial cooperation was again blocked by Greece in a dispute over a pair of rocks three miles of the Turkish holiday town of Bodrum. This phenomenon, which has now lasted a total of 18 years, not only continues to damage the Union's credibility but currently costs the Union money and jobs in lost ontracts which would have accrued, especiall from the frozen EIB loans of 750 mecus. It is not the money which counts ... The loss is psychological and political; it saps trust and confidence in the relationship".

When the Association Council has adopted the Decision 1/95 "establishing operating rules for the final phase of the customs union", it also adopted a Resolution which pointed out that it was "particularly important to supplement the agreements concluded within the framework of that Decision by implementing other aspects of the Association". The Resolution "considering the political agreement reached to date on the substance of a Decision establishing operating rules for the final phase of the Customs Union", clearly establishes that the Decision concerning Customs Union is not an end in itself but is only a beginning which should be supplemented by a series of comprehensive co-operation projects. The Association Council declares that it "deems it necessary to start an appropriate dialogue between two sides on the conduct of macro-economic policy in order to ensure the best macro-economic environment possible for the functioning of the Customs Union".

How can both sides ensure "the best macro-economic environment possible for the functioning of the Customs Union ?" The answer to this question was given in the Community Declaration on financial cooperation : ".. Turkey will need substantial financial resources, in particular long term loans and technical assistance, in order to adapt its industrial sector to the new competitive situation created by the Customs Union".

In fact, it was declared that the Association Council "deemed it essential to broaden the scope of operation between the European Union and Turkey" and looked forward to seeing initiatives being taken in the following fields : Industrial cooperation, Trans-European networks, cooperation on energy, transport, telecommunications, agriculture, environment, scientific cooperation, statistics, matters relating to justice and home affairs, consumer protection, cultural cooperation and information and communication. Under a separate title "co-operation on social matters" is mentioned whereby "a regular dialoque" is to be established on "the situation of Turkish workers in regular employment in the Community and vice versa". (Unfortunately, there are still various cases at the European Court of Justice concerning the Decisions of the Association Council back from 1980 on social security and related matters which should have been settled by now.)

Thus, the Association Council Decision concerning the customs union, together with the Resolution which pointed out that it was "particularly important to supplement the agreements concluded within the framework of that Decision by implementing other aspects of the Association" described the route for the future. In order to achieve these aims, of course, financial cooperation was essential. After the Association Council Decision, the Commission drafted a proposal for a Council Regulation regarding the implementation of a "Special Financial Cooperation Measure for Turkey". In line with the Community undertaking 
towards Turkey in conjunction with the customs union, the draft Regulation declared that "The Community shall make a contribution to back Turkey's efforts to strengthen its social and economic infrastructure and improve the competitiveness of its economy as part of the final phase of establishing a customs union" (Art.1).

It was thus underlined that the projects and programmes funded by the resources allocated for this special measure should be used primarily, to help strengthen Turkey's economic structure to cope with customs union and to back Turkish Government's programme of reform which is seeking to modernize the economy, improve social and economic infrastructure, consolidate democratic practice and give civil society a greater role in the country's development. Similar to Cohesion Fund and other Community projects, the "Special Financial Cooperation Measure for Turkey", in its Art. 3 referred to "negative effects which the structural adjustment process may have in social terms and with regard to employment, in particular for disadvantaged population groups". Thus this special financial cooperation measure was aiming to help to alleviate "the negative effects of structural adjustment process". This Draft Regulation covered a rather symbolic amount of 375 million ECU for a five year period but the total amount promised by the European Community was over 3 billion ECU.

It was clear that customs union could not be envisaged without a comprehensive financial support mechanism. In order to broaden the cooperation in other fields covered by the Association Agreement, additional support was to follow. However, these could not be activated due to a continous Greek veto, this time the reason declared was "because of few rocks off the coast of Turkish holiday town Bodrum". It was absolutely clear that the best method to block Turkey-EC Relations passed through the torpedoing of the financial cooperation. In spite of a clear and definite Community undertaking concerning financial cooperation which should have started in 1995 nothing was achieved for more than three years.

In October 1998, the Commission drafted proposals for a Council Regulation based on Article 130 w of the Treaty, which provides "development cooperation", to further the following objectives : "the sustainable economic and social development of the developing countries, and more particularly the most disadvantaged among them ; the smooth and gradual integration of the developing countries into the world economy; the campaign against poverty in the developing countries" (Art. $130 \mathrm{u}$ ). Under this Article decisions may be taken by a qualified majority rather than unanimity.

The preamble of the draft Regulation refers to efforts made by Turkey to ameliorate its economy by implementing substantial reforms, to restructure and improve the efficiency of its public sector and argues that since revenues are not shared equaliy between different provinces of the country, and since the Cardiff European Council has underlined the link between the support to develop the backward regions and the economic and the social cohesion, a sum of 135 million ECU for a three year period would be made available. It was reported that Commission's proposals of 21 October 1998, to the Council, aimed at releasing EU financial assistance for Turkey are not intended to implement the financial chapter of the EU-Turkey customs union but is designed "to develop the new European 
Strategy for Turkey" proposed by the Commission in March and welcomed by at the Cardiff Summit in June 1998. The second draft Regulation, which was based on Article 235 and required the unanimity of all the member states, had a budget of 15 million ecu for a period of three years, in order to support Turkey in the process of the approximation of its legislation, supporting Turkey's inclusion into the European rules of origin system and its participation in regulations on transit. (Bulletin Quotidien Europe, 22 October 1998 p.8). According to the same agency, the Greek Commissioner accused his colleagues by saying that they were entering into "legal acrobatics" in order to get a Regulation passed for the implementation of Community obligations towards Turkey. Eventhough, the funds involved were less than a "symbolic amount", the following day, the same news agency reported that "Greek authorities reacted quickly to the Commission intiative" and claimed that the proposals represented "a dangerous precedent which should concern all member states as it brings into question the possibility of using veto in an area of vital interest". Apparently, a community credit as small as 50 million ECU a year to Turkey, which is in fact part of the customs union together with the fifteen member states, constitutes a threat to Greek "vital interests". Greek Ministry of Foreign Affairs also announced that they will refer the matter to the Court of Justice in Luxembourg. No need to mention that the amounts being discussed can not even be interpreted as a symbol which has no relationship to the magnitude of the customs union project and constitutes a mockery for the proportionality principle. In any case already the European Parliament has made some counter proposals that will make it very difficult to implement these Regulations. As elections are approaching the matter will not be decided by the Parliament before June 1999. There can be no doubt that the Commisssion can be more active and encourage the MEP $s$ to act expeditiously. On the other hand it appears that preparations have begun for MEDA II but for Turkey a reduction was made in her share both as grants and as credits on the ground that consideration given to the amount provided from the Special Action Programme (SAP) for Turkey-EC customs union. Naturally, the SAP was envisaged.

For Turkey solely for the well functioning of the Customs Union and should not have been considered for anything else and as the relevant legislation for SAP was never issued, Turkey was left with only a limited resource and a meagre sum compared to the other Mediterrenean partners. Since Turkey represents 33 per cent of the GDP of the Mediterrenean countries, as well as 30 percent of its population MEDA II should be increased substantially, taking into consideration the size and needs of Turkey.. Whereas EC continues to expand its trade surplus with Turkey -around a quarter of the overall trade surplus EU achieved with the rest of the world originates from Turkey-EU continues to fail to implemenet its financial obligations towards Turkey. Not only the Government sources but also the Turkish private sector believes that EU has no solidarity with Turkey and has left her alone to cope with the new competitive environment. In spite of the clear and unconditional EU undertaking in 1995 Association Council for financial cooperation which has been entered into the minutes of the Council, it is clear that EU is leaving Turkey alone again in the preparation for accession and will not support adequately the structural adjjustments Turkey is expected to make. When the extensive programs within the framework of the pre-accession process of other candidate countries is taken into consideration the unfairness against Turkey becomes more 
disturbing. The hostility and bias towards Turkey has already reached such a stage that many people in Turkey wonders whether this is the rebirth of the "Crusaders mentality".

After studying the pre-accession and development aspects of Turkish association agreement, we should focus our attention to the Luxembourg European Summit and its decisions which claimed that it "marked a moment of historic significance for the future of the Union and Europe as a whole". However, on 4 March 1997, several months before the Luxembourg Summit, an "Extraordinary Summit" of EPP (European People's Party) was held in Brussels, at the invitation of Wifried Martens, Chairman of the EPP. According to some observers, the most important item of the EPP agenda was Turkey and the decision of this gathering shaped the Luxembourg Conclusions.

\section{European People's Party (EPP) Summit of March 1997 : Project of Civilization}

This extraordinary summit of the EPP was to give the participants "the opportunity to discuss informally and in detail two main subjects". According to the press release of the EPP Chairman, one of these subjects was "the enlargement of the European Union", the other being the intergovernmental conference. The summit brought EPP Heads of Government from Germany, Italy, Spain, Ireland and Luxembourg together with the presidents of the European Commission and the European Parliament. Although the meeting was described as an "informal" summit, the reports appearing in the European press the following day, described the repercussions of this meeting. Indeed, the Volkskrant of the Netherlands, had the following report by Jos Klaasen, entitled 'Admission of Turkey into EU is Unacceptable' : "The Christian Democratic European People's Party is absolutely against Turkey becoming a member of the European Union. Party chairman Wilfried Martens did not leave a shred of doubt about that yesterday. The Turkish membership of the Union is unacceptable to the EVP. Never before has this been stated in such an outspoken manner".

The paper noted that, Wilfried Martens' "No" carried "enormous weight" as he happened to speak with Chancellor Helmut Kohl of Germany, the Spanish Prime Minister Jos Maria Aznar, the Belgian Prime Minister Jean Luc Dehaene, the Italian Prime Minister Romano Prodi and Chairman Jacques Santer of the Commission who all attended the summit. According to the Volkskrant :"Martens wishes to have a "very close cooperation' with Turkey. But, for him that is something completely different than the process which is going on in Europe at present: that involves something 'European' and also a 'civilization process'."

The Italian daily, La Stampa reported that "Top European Christian Democrat leaders yesterday, in a move which could have a very serious consequences for Turkey's stability, closed the door to Turkey." Indeed, Fabio Squillante noted that "the Chairman of EPP, Mr. Martens slapped Ankara diplomatically by announcing that Turkish membership is unacceptable. "Volkskrant of 6 March 1997 had another article by Klaassen : "The European People's Party (EVP) has thrown the door to 'Europe' shut for Turkey. The Turks are welcome as good neighbours. But a member of the European family they are not, and they never will be. Turkey's joining of the EU is 'unacceptable' to the party. All of a sudden the arguments which Europe has been using against Turkey all the time prove to be nothing but hypocrisy. The Turkish violations of the Human Rights ? Cyprus ? The great social-economic backward positions of Turkey? 
With hindsight we are to conclude that they have all been but cowardly excuses. For the EVP Chairman Wilfried Martens -unanimously supported by Helmut Kohl, Jos Maria Aznar, Romano Prodi, Jean Luc Dehaene, Jean Claude Juncker, Jacques Santer and John Burtonthe Turks cannot become members of the Union, because they are not Europeans. His literal text : 'We want the closest relations with Turkey, but we are building a European Union. Martens' emphasis on 'European' implies that he -and the EVP - does not regard Turkey as a European State. Europe ends at the Bosphorus.

But why then Turkey was admitted to the Council of Europe? And why Turkey since 1952, been accepted as an avant-garde member of the Atlantic Alliance ? Was it so that the Turks did happen to be good enough to defend the western values against the evil empire of the Soviets? Now the true European colours finally seem to be showing, the Turks must surely feel betrayed, for over seventy years they have been oriented towards West. The father of modern Turkey, Kemal Atatürk, after all pointed his people towards the West. The Turkish Republic, which was declared in 1923, was not to be governed by Islam. From one day to the next, western laws and values became the guideline for the entire society, ever since the modern Turkey has considered itself as part of Europe. When Turkey applied for membership in 1987 EU should have immediately say No, if she was of the opinion that Turkey did not belong to the European family. Fundamentalism is receiving additional impulses from the news that to the Christian-democrats from Brussels Turkey is 'unacceptable'. Many Turks already happen to believe that the European Union regards itself as an exclusive Christian club, which will never accept an Islamic country."

The summit meeting of the EPP, according to some commentators, opened, a long time "taboo", that is the "Moslem State of Turkey", to discussion. Marc Guillet in Algemeen Dagblad of 6 March 1997 was very clear in his observations : "The debate about the concealed arguments for which Minister Van Mierlo called upon in the European Parliament a month ago, has broken in all intensity. He meant that the arguments that are being used within doors behind by several EU-member States to say 'No' to the Turkish admission to the EU. One of those arguments is the 'danger' that millions of unemployed from Anatolia will spread accross the European Union to try their luck there after the integration of Turkey. The other argument was worded in Brussels on Thursday by Chancellor Kohl and five other Christian Democratic prime ministers. Ankara can never become a member of our club. Because the Turks have a different culture and miss our Christian-humanistic orientation. In other words : Turkey, a big Moslem State in Asia is a Fremdkörper-an alien body- that does not fit in our Christian Europe. According to Marc Guillet, "after having been hidden for decades behind a smoke-curtain of other objections, "like democracy, human rights, economic situation, huge inflation, Cyprus-issue, "the big taboo has finally been placed in the spotlight".

Algemeen Dagblad, after noting that most of the reactions were negative, quotes M.Birand, the veteran among the Turkish columnists, who writes about Europe for almost three decades : "I am schocked and disappointed. It is the 'biggest blunder' in the history of the EU. Kohl and his Christian democratic friends are rendering a big service to the Muslimfundamentalists in Turkey. In this way Turkey will be isolated and driven into the arms of the Islamic countries.' He wonders perplexed why the six Government leaders have not chosen 
for a more subtle approach. 'Communism is dead. Now the Moslems are all simply seen as one big group and considered to be the enemy, no matter what their political ideas are. The message obviously is : We could not care less about what is happening in Turkey.' Turkey has been loyally cooperating for 46 years with the common defence (NATO and WEU) and has helped protect West- Europe against the Soviet-Communism. Ankara cooperates in the political field (Council of Europe) and since 1 January last year-1996- there are also close economic relations (Customs Union) with the EU. Turkey made an Association Treaty in 1963 with the former EEC in which a perspective for admission was offered. Despite that, Brussels has kept Turkey dangling for years. Ankara filed a formal request for admission in 1987. Two years later the European Commission said that it 'was too early' to begin the negotiations. Meanwhile ten years have passed and the $E U$ is on the eve of the 'big leap forward.' Eleven member States among which Bulgaria and Romania (not the very pictures of democracy, exemplary human rights and healthy economies either) will get a place in the 'family portrait' at the European Summit in Amsterdam in June. Ankara feels enormously hurt that despite its long record of service it is being treated by Brussels as a second rate State and that no perspective is offered for admission." The report in Algemeen Dagblaad also quoted a Turkish diplomat. "Europe must not create new cultural contrasts now that the ideological iron curtain has fallen." Same newspaper, in another report, also noted that "The abrupt rejection of a Turkish EU-membership.. has led to big commotion in Brussels and Ankara. Turkey feels 'deceived' and and 'lied to' but despite this will continue its efforts to become a full member of the European Union."

The leading editorial of the Algemeen Dagblad, on 7 March 1997, underlined that "with their premature and insulting rejection of Turkey as a full member of the EU the Christian Democratic Summit in Brussels did not benefit the case of Europe. The ascertainment that by the CDA Euro-parliamentarian W. Van Velzen that Turkey does not fit into Europe "because it lacks our christian/humanistic orientation' is certainly not an argument. Even stronger so, it is an enormity because it does not do justice -out of obstinacy, because of ignorance? ? to a rich culture and tradition that is not at all second to the christian one. And it is a dogma because the real cause of the rejection is still being concealed...There are indeed geo-political and economic reasons that can be brought up to admit Turkey to the EU in the long run. Not in the last place because Europe must also be able to count on a partner that is buffer and bridge between itself and the turbulent middle-east, the Balkan and the Caucasus in the future."

The reaction of the Turkish press to the announcement made by the Christian-democrat parties was not any different then the Volkskrant. The leading Istanbul daily paper Hürriyet had the following title: "A schocking announcement concerning EU membership". Another daily Radikal reported : "European door closed. Christian democrat leaders reached consensus on Turkey's EU membership being impossible. While referring to the EU as a 'civilization project', it was declared that "Turkey has no place in it" Whilst, Milliyet reported "Bad News from the European Union", Cumhuriyet headline said "Turkey cannot be a member of the EU."

British Foreign Office made the following statement when asked by the Turkish Daily News : "We believe each applicant country should be dealt with an objective criteria which 
should not include religion and cultural background of the country.. The UK is a close ally of Turkey and wishes to see it in the European family when necessary reforms are made." According to Financial Times (6 March 1997) Foreign Secretary Mr. Rifkind "distanced himself from this week's statements by west European Christian Democratic leaders, who suggested Turkey was not European because it did not share the EU's christian values." Socialist member of the European Parliament and the co-chairman of the joint parliamentary committee, Mr. Dankert in his remarks during the plenary session strongly criticized the EPP decision. Ms. Claudia Roth of the Greens accused the Christian Democrats of "their usual Doublespeak" and "hypocritical" attitude in a Press Release dated 7 March 1997 in Brussels: "Human rights abuses in Turkey were stated as a reason for preventing the accession of Turkey to the EU, but this was just a cover for what they were really saying. When Wilfried Martens, president of the EVP, refers to a 'civilised society', he is actually talking about guaranteeing Christian culture, and not about guaranteeing human rights. However, religion should not be a barrier to joining the EU."

\section{Luxembourg European Council}

Whereas Turkey regarded the customs union as the last stop before full membership-(with a direct reference to Art. 28 of the Association Agreement in the Preamble of the Decision $1 / 95$ of the Association Council), the Union apparently did not see it that way in spite of clear Treaty obligations. In the Apeldoorn understanding of the Council the Member States agreed that "Turkey would be treated according to the same objective standards and criteria as all other countries". Certainly it would only be natural to treat Turkey according to the same objective standards and criteria as all other countries, but even such an undertaking was regarded as "an important and qualitative advance" by Ambassador Lake: "It was approved by the Association Council of April 29, 1997, and is thus part of the Acquis Communautaire."

It was in Luxembourg Summit meeting of the Heads of State and Government of the European Union that "a new and comprehensive enlargement process" was launched on 12 and 13 December 1997 with the announcement that six countries, Poland, Hungary, Czech Republic, Slovenia, Estonia and Greek Cypriot Administration was going to start accession negotiations almost immediately -at the end of March, 1998. There was a second group of countries which would have to wait somewhat longer, but they would benefit from closer economic ties through "accession partnerships". They included Bulgaria, Romania, Latvia, Lithuania and Slovakia. It was also pointed out that "all these states were destined to join the $E U$ on the basis of the same criteria and they will be participating in the accession process on an equal footing".

"A single framework for these applicant countries" is established and "enhanced preaccession strategy", framed in Luxembourg is intended to enable all the applicant states to become members of the EU. The strategy thus centers on "accession partnerships" and increased "pre-accession aid":- "Accession partnership", according to Luxembourg Conclusions of the EU Council, "will mobilize all forms of assistance to the applicant countries of Central and Eastern Europe within a single framework which will cover for each aplicant, the priorities and the financial resources available for that purpose." It was announced that pre-accession aid was being increased substantially which, as from the year 2000 will 
compromise aid for agriculture and a structural instrument which will give priority to measures similar to those of the Cohesion Fund. It was also noted that financial support to the countries involved in the enlargement process was to be based on the principle of equal treatment, independently of the time of accession.

It was pointed out that the meeting in Luxembourg on 12 and 13 December 1997, "marked a moment of historic significance for the future of the Union and of Europe as a whole" with the launch of the enlargement process. It was alleged that we could see the "dawn of a new era, finally putting an end to divisions of the past. Extending the European integration model to encompass the whole of the continent is a pledge of future stability and propserity".

The Luxembourg Summit, after deciding to launch "accession negotiations" with the Greek Cypriot Administration in Cyprus, in violation of the Treaties and the 1960 Constitution, argued that the "accession negotiations", which actually means the transfer of certain sovereign powers of the acceeding state "will contribute positively to the search for a political solution to Cyprus problem". This search for a 'political solution', of course, means to draft a new constitution for this country. Thus, Luxembourg Summit, actually the EU appears to think that you can draft the Constitution of a federal state, while negotiating its accession to a supra national institution like the E.U. Luxembourg European Council also finds an extraordinarily exciting model for the negotiating team : Representatives of the Turkish Cypriot "Community", will be included in the accesssion negotiation delegation" of the so called the "Government of Cyprus" which has no constitutional legitimacy. The fact that it is recognized by the U.N. and others does not remedy the unconstitutionality of the regimein the south.

Luxembourg Summit, in this "comprehensive, inclusive and ongoing process of enlargement where all these 11 states are destined to join the European Union on the basis of the same criteria and that they are participating in the accession process on an equal footing created a totally different and indeed discrimination towards Turkey.

Turkey was not going to take part in this "comprehensive, inclusive and ongoing process of enlargement", but would be most welcome to what they called the "European Conference" which will be a"multilateral forum for political consultation", intended to address "questions of general concern to the participants", and "deepen their cooperation on foreign and security policy, justice and home affairs" and "other areas of common concern". Even attendance to this conference was subject to a number of conditions imposed by a member State, apparently at the last minute of the Summit.

Whereas some observers, who claim to be "friends" of Turkey, while looking directly into our eyes, still argue, that Turkey misread the "Luxembourg Conclusions", it was obvious that objective observers in press had no difficulty to understand the real meaning of Luxembourg. Therefore, below, we will provide an unusually extensive selection of press comments. Since there are still those, who argue that Luxembourg was actually in favour of Turkey, even recognizing Turkey's "eligibility" for membership etc., apparently confirming the arguments that many of our "friends" still think that the Turks will continue to believe whatever is told to them with good-faith a reminder is required: Though it is indeed very unfortunate, it must be known that the Member States and EU institutions have lost so much credibility that even 
when they will make true and sincere statements there will not be that many who would believe them anymore. Now we may review the press comments on the Summit. Was Luxembourg really in favour of Turkey?

In fact, many days before the Luxembourg Summit, the expected result was evident. On 9 December 1997, Hans Heinz Schlenker in Salzburger Nachrichten reported that "Greece could torpedo the Luxembourg Summit. If Greek demands would not be met, no decision may be taken." A day before the Associated Press quoted the Dutch Foreign Minister saying "We should not hurt the Turks." Yorgas Kouvaras in Athens daily, Ta Nea, on 9 December 1997 reported that "Greece insists on the veto". Therefore, the approaching storm was evident, eventhough Mr. Van den Broek, the Commissioner in charge of external affairs said in an interview that "Turkey should be at the same line as the other candidates". This was considered the first major change in the Commission's position since July when it excluded Turkey from enlargement

After the Summit, an Editorial Comment in Volkskrant on 15 December 1997 noted that "the Luxembourg summit has failed in one respect with the attempt to pacify Turkey by offering an empty shell with the label of 'this is half an egg'. The EU not only refused to offer a concrete prospect of a Turkish membership, but even posed simple political consultations and a whole series of conditions. Not all of those conditions are without sense, but the way they have been presented has been so blunt that the Union has in fact allowed itself to be used as an extension of the Greeks and has made the Turks feel themselves treated as not even second rate, but rather a third rate power. The chance of a sharpening of the Cyprus conflict is very real, as a result of this unimaginative and risky European policy."

On the same day Volkskrant had another article on Luxembourg which was entitled "EU leaders allow Greeks to 'Hi-Jack' the Summit". According to the Dutch paper, the "historic summit" on the "Great Reconciliation in Europe" has progressed in a far less festive manner "than everyone had hoped. "The European Union has considerably broadened its prospects for expansion towards the East, but on the Southern flank a new wall has been erected. The little party of the fifteen EU leaders with eleven Eastern European colleaques was not exactly a total wash out, but today's hangover does not feel any less bad because of it."

Volkskrant observed that "the new demarcation line through Europe now runs between Greece and Turkey. Europe has slammed the door in the faces of the Turks, and it may well take until the middle of the next century, before it will open again. Or so concluded a bitter Dutch diplomat. "The Greeks have high-jacked the summit."

The following comments of the Dutch paper appears to support the opinion of Ambassador Lake who served in Ankara for seven years as Commission representative, which we referred elsewhere in this paper : "Earlier this week it did not look as if Greece would be getting its way. With the tough position it adopted, Athens mostly caused irritation with most of the other countries. Although none of them wanted to make Turkey a member to the EU anytime soon, they, in any case, wanted to keep the door open. Turkey is too important to openly offend the country in such a manner. Which is why the EU is said to be doing its utmost in order to find a compromise, in which Turkey would not be receiving too much, but most certainly also not too little. But in Luxembourg the Greek Prime Minister Simitis and his crafty 
Minister of Foreign Affairs, Pangalos, got a free hand. Many leaders made little effort in order to prevent painful breach with Turkey. For some that is not so surprising. Chancellor Kohl, who does not harbour any warm sentiments towards the Turks, felt but little need, over the past couple of days, to fiercely oppose the Greek strategy. On the contrary, he thought it was rather pleasant that the Greeks were picking the hot chestnuts from the fire. But where was Great Britain, where was France ? The Netherlands regarded in the EU as one of the biggest defenders of the Turkish interests, often formed a united front with London and Paris, over the past couple of weeks. But on Saturday, that was not the case. At certain moments it seemed as if it was just the Netherlands against Greece and that was something which Van Mierlo and Kok deemed to be going a little too far. Blair remained remarkably quiet. Also France offered but little in the line of a counter action. According to some diplomats the machine of the 'cohabitation' between President Chirac and Prime Minister Jospin was not exactly running smoothly with regard to this matter. The most remarkable, however, was the role which was played by the Luxembourg Prime Minister. He is one of the Christian Democratic leaders, who, at the beginning of the year 1997 openly stated that the Islamic Turkey could not possibly form part of the Christian club, which is called the European Union. Kohl also subscribed to this standpoint, which called forth fierce reactions in both Turkey and the EU. Ever since then the Chancellor has not made any statements about it anymore. The young Luxembourg Prime Minister ('Junior Junker' according to friend Kohl), obviously has no interest in circumspect diplomacy. In an interview, Junker expressed his revulsion of the torturing in Turkey, the military threat on Cyprus and the provocations against the neighbouring country of Greece. Although that criticism may be true as far as content is concerned, it is highly questionable whether he has not interpreted his mandate as chairman in too liberal a manner. With his unusually harsh criticism he only widened the gap between the Union and Turkey. In doing so, he himself was also reponsible for the damper which cooled down relations." According to the paper, Kok was critical with regard to the statement which the government leaders finally agreed upon : "It largely carries the stamp of Greece. It just so happens that the slowest camel sets the pace for the whole caravan. According to Kok, most of the European countries would have preferred to see a more accomodating attitude towards Turkey, but the Greek Prime Minister Simitis proved to be irreconcilable. Diplomats interpreted the European position adopted as a resounding victory for Greece. 'The Greeks have got their way practically with everything. With the remainder of Europe people lacked the courage to go to head over this' said a Dutch diplomat. Several different government leaders tried to disguise the tough conditions, afterwards, and spoke of a historic offer, which had been made to Turkey. " 20

Athens News Agency ANA on the same day reported that "Greece has every reason to be pleased, simitis says after EU summit. Prime Minister Costas Simitis expressed his absolute satisfaction over the results of the European Union's summit in Luxembourg, shortly after the close of two day summit on Saturday, stressing that Greece has every reason to be satisfied". If the so-called "pro-European" and "moderate" Greeek Prime Minister is so irreconcilable, one wonders what a Greek leader without such qualities would do.

Panos Loukakos writing in Vradini on 16 December 1997 had a very interesting headline for the EU summit : "A Strong National Front Against Turkey". Loukakos reported the following : "In Luxembourg all Greek conditions for Turkey's EU relations has been accepted". 
After referring to Cyprus, he notes that "the result was a 'Greek Victory' or 'Turkey's Defeat' which could be understood from Turkey's reaction. Greece should be ready to a new serious crisis in her relations with Turkey". Akis Kourkoulas in Kathimerini under the headline "The Only Road Open for Ankara," also reported that Greek Government officials talking about "National Success." A. Podimata, in Athens daily Eksusia, also on 16 December 1997 reported that "Turkey lived its most difficult day in her contemporary diplomatic history".

Josef Joffe in the Suddeutsche Zeitung, of 15 December 1997, under the "Hegel and European Turtle" title made this comment : "Rudely the answer to Turkey was a NO. This demonstrated how far is the EU from any strategic considerations which wants to show itself as a big power."

Herman Tertsch, writing about "Turks and Europe" observed : "Luxembourg has not only left Turkey at the door but also distanced her. For that reason Ankara's reaction is understandable." In Spanish daily El Pais, on 15 December 1997 he made the following comments : "The European Conference which Turkey angrily refuses to attend, will not be good for anything except to show the Turks twice a year where they are and not expected to be a full member. It is not logical that Turkey Policy of Europe should be dictated by Greece. European policy should not be left hostage to nationalistic mythologies, historical clashes and Balkan paranoias. The slapping the face of Turkey systematically may have serious consequences. Especially, a conflict of interest like Cyprus cannot be shown like a sin of Turkey who had nothing to do with Colonels of the Greek Junta. Many Europeans imagine Turkey as described in film "Midnight Express" with its police and soldiers; Greece and some other Member States think that it is to their interest that this image should continue. However, Turkey has beeen a European State for centuries."

The editorial of Trouw on the same day had the following title : "Shamefull". According to Trouw, "the European Union has opened the door to Eastern Europe and slammed it shut for Turkey. A historic decision with a dark little edge. While they are embracing Eastern Europe, the European government leaders are excluding Turkey. Last week, the country was given the message that it was not welcomed in Luxembourg. Europe is using a double standard and the language with which that is done is quiete shamefull."

De Telegraaf on 15 December 1997 referred to another aspect : "By not giving the membership perspective to Turkey, Europe has strengthened the hands of the fundamentalists in Turkey".

Former Under-secretary of German Defence Ministry Lothar Ruhl, writing in Die Welt on 13 December 1997, under the title "Turkish Acrobatics", commented on the "new formula" the so called "customs union + plus", and argued that this could be qualified as "Europe Light." Herr Ruhl noted that such formulas are nothing but simple attempts "to keep Turkey at a distance outside Europe". Indeed, he argued that "it was easier for a camel to pass through the needle eye than Turkey entering from the Brussels gate." Suddeutsche Zeitung on the same day noted on the so called "Strategy to bring Turkey closer to the EU". According to the German paper, this strategy does not have any other meaning than Turks may not enter the EU. Turks would be a burden on the EU from financial point of view. Also Turkish workers would flood the EU countries which already had unemployment problems. 
Kinkel says in a diplomatic fashion that Turkey should slowly brought closer to the EU under the strategy. This probably means that after trying everything for more than thirty years, Turks will have to wait at least 99 more years. If Turkey is not wanted, the reasons should be made clear. For the EU countries the human right violations do not constitute the priority role. It is not possible to be convincing with a number of pretexts and excuses.

Jyllands-Posten, a Danish paper on 16 December 1999, had an editorial entitled "Cold Turkish Bath". After noting that nobody could claim that "the weekend's summit in Luxembourg of being a display of the more elegant sides of diplomacy", the editorial continued: "With a clear political attitude the EU Heads of State and Government decided to invite Cyprus and ten other Central and East European countries in from the cold whereas Turkey was left outside in the winter cold. Turkey submitted her membership application in 1987. At the time 10 of the 11 countries, which are now in the positive list, were still members of the Warsaw Pact. It is difficult to follow the motive why Turkey should have such a cold and unfeeling shoulder by EU as the case was in Luxembourg. Others referred to the unsolved territorial disputes between Greece and Turkey without the necessary addition, that Greece carries her great responsibility for the missing solution. Turkey, who ardently wants to become part of Europe was not deftly shuttled onto a sidetrack in No Man's Land. This is not a way to treat a country that constantly offers friendship. EU's cold shoulder can only serve the interests which are trying to drag Turkey away from Europe and into the medieval darkness of the Islamic fundamentalism."

According to Danish paper Jyllands-Posten, "EU must as soon as possible mend its relations with Turkey and get formulated what the Union so clearly lacks today : A long term and unambiguous policy in relation to the country on the crossroads between Asia and Europe".

Repubblica of Italy, on 16 December 1997, followed up the EPP Christian Democratic Parties declaration earlier in the year in Brussels to the effect that "Europe was a project of civilization" and Turkey had nothing to do with that. Bernardo Vali had the following title : "A Christian club not open for Turks : Europe a Christian Fortress".

The Luxembourg Summit was an open discrimination and almost total exclusion. It was obvious that Turkey was not evaluated within the same framework, the same well intentioned approach and objective criteria as the other candidate countries. Naturally, Turkey considers its candidature for full membership of the EU, a right deriving from the 1963 Ankara Agreement. Such a brutal discrimination against an associate member for 34 years, a NATO ally for more than four decades, a country with a full customs union, thereby adopting all aspects of the Common Commercial Policy of the Community and most of its acquis, ranging from competition policy to industrial and intellectual property, could not be taken lightly. It was clear that Turkey's future and its relations with the EU, which Turkey considered extremely important, could not be built on such an uncertain ground.

As the coming storm was evident, in spite of such an irresponsible and scandalous action from EU, Ankara still was hoping to control the crisis and aiming to limit the damage to the relations between two sides. In fact, in anticipation of the Luxembourg summit, during which 
the overall enlargement process and the future of the Union was to be established, the Government of Turkey disclosed its expectations in a reasonable and realistic framework. In a series of contacts with Member States and the Community institutions, Turkey made it clear that it was not expecting to become a member in a very near future.

Ankara was fully aware that there were numerous sectors which required extensive reforms, even after the customs union and efforts to achieve these objectives would continue. The constructive approach taken by this associate country also reflected the awareness that the measures to be taken included some reforms in macro economic field and further improving the implementation of basic principles of human rights and democracy.

When Luxembourg Council claimed to "mark a moment of historic significance for the future of the Union and Europe as a whole", with a "comprehensive, inclusive and ongoing process" of enlargement; including many post communist countries many of which are still far behind Turkey, not only economically but also in many aspects of socio-political structure, the Union was actually excluding Turkey from this process. Naturally, this could not be taken lightly by Turkey.

Luxembourg Summit, (coming after the unfortunate declaration of European Christian Democratic Parties announcing that based on "religious grounds", Turkey could not join the EU) was pushing Turkey outside the future architecture of the European Union, while opening an enlargement process which will double the number of member states.

\section{What was the reaction of Turkish Government to Luxembourg ?}

It was obvious that "unless such a negative approach and mentality was changed" one could not expect Turkey-EU relations to be developed within a constructive and multifaceted dialogue. Naturally, in such negative atmosphere, with remarks not only exhibiting bias and prejudices, but also displaying totally unjustified discrimination towards Turkey, it was not possible to establish a cooperation environment covering political issues which are not of direct and mutual interest to both parties. On top of that attempts to impose political conditions, inserted in the last minute by a member state, in Turkey-EU relations, could not be accepted. Indeed, it was clear that EU's position, as it was declared, was far from constituting a "sound and credible" basis for political contacts. Turkey's future and its relations with the EU could not be built on such an uncertain and slippery ground. It was up to the EU to display the virtue of not insisting on the "erroneous and harmful path" that it was taking in Luxembourg.

Turkish Government's evaluation of the Luxembourg Council conclusions were well balanced. Every effort was made not to damage the existing association relations. In fact, whereas the Luxembourg Conclusions on Turkey was totally "irresponsible", Ankara reacted in a responsible manner. It was announced that "EU-Turkey relations was to continue with determination and confidence to advance on the path drawn by Atatürk and its will for integration with the EU despite the position laid out at the Luxembourg summit". The customs union would continue in spite of the continuing default of the Community in its obligations and committments towards Turkey in terms of financial support, which is, of course, a sine qua non aspect of the CU. Although more than a year passed since these proposals were put forward, no progres has been achieved so far. It is hoped that it will not have the same fate of previous EU proposals and "packages" the Matutes plan etc. 
Although Turkish Government's reaction was restrained and did not result in completely breaking relations with the EU, Algemeen Dagblad, on 17 December 1997, reported that "Turkey's decision to break off the political dialogue with Europe has caused a schock-effect. Yesterday, several European Ministers openly distanced themselves from the final statement of the EU-summit in Luxembourg on Saturday. In that statement Turkey was excluded from joining the European Union for now. One minister after the other expressed their regret about the way the Turks had been treated when they talked with the Turkish Minister of Foreign Affairs Cem. Minister Van Mierlo said that 'it had not been the wish of the fifteen member States to say what was said in the final statement'. He blamed the Luxembourg Prime Minister and EU Council chairman Juncker of not having been sufficiently clear about the conditions that were stated to Turkey by the EU, are not 'conditions in advance'. Van Mierlo also spoke of an 'understandable reaction of the Turks.' If we take Mr. Van Mierlo's statement that 'it had not been the wish of the fifteen member States to say what was said in the final statement,' we can understand the difficulties Turkish policy makers have on EU matters: It appears that summit statements made by EU does not necessarily indicate that they wished to make such a statement. Turkish policy makers will have to "discover" whether the fifteen member states really wished to say what they actually said in the Conclusions. No wonder reports from Ankara quote top Turkish officials saying that they lost confidence in the EU.

The attitude of the EU and some Member States during fugitive Ocalan's sejour in Italy, where he was "arrested" based on a German Court order, destroyed the credibility of the EU or whatever was left of it. Whereas Germany refused to make a request for an extradition, Italy violated her International Law obligations on extradition and conventions for the supression of terrorism. Although Rome could be justified for its refusal to extradite, it should have prosecuted the terrorist fugitive in accordance with the well known maxim "extradite or prosecute". Italy did neither and the Prime Minister announced that "Ocalan left the country and he did not care where he went." When Italian Minister of Justice ordered the release of the terrorist, private organizations and various consumer groups in Turkey organized a very effective private boycott campaigns against Italian products. The Commission President, which should be fully aware of the fact that EU was not fulfiling its Treaty obligations towards Turkey even dared to talk about measures of "retaliation" against Turkey, whereas the Turkey Desk Officer in the Commission was talking about "mentality differences". Furthermore, when the Greek Government was caught red-handed in Ocalan affair and their support to the separatist terror organization became undeniable, neither Greece nor the PKK was condemned by the General Affairs Council. Whereas the Human Rights Commission of the Council of Europe qualifies the PKK as a terrorist organization and whereas there are more than a dozen Judgements of the German Courts to the same effect, EU Council hesitated to call the PKK as a terror organization.

\section{European Strategy for Turkey and Cardiff European Council}

In March 1998, the European Commission announced a "European Strategy for Turkey", to prepare the country for accession, by bringing it closer to the EU in every field. This strategy is to consist of the following : Development of the possibilities afforded by the Ankara Agreement, intensification of the customs union, implementation of financial cooperation, 
approximation of laws and adoption of the Union acquis, participation to be decided case by case in certain programmes and in certain agencies. It was also underlined that implementation of most of these proposals will depend on the financial resources available for Turkey and notably on the implementation of the "Special Action".

These new proposals in industrial cooperation and investment, agriculture, services, greater substance for the customs union, approximation of legislation, closer technical consultations, dialogue on macro economics, telecommunications, environmental matters, transport, energy, and especially institutional cooperation and political dialogue was all welcomed. Commission underlined, once again, the importance of financial cooperation, in order to enable this strategy to be implemented.

Six months after the Luxembourg Summit meeting, Heads of State and Government of the fifteen Member States meting in Cardiff on 15 and 16 June 1998, welcomed the Commission's confirmation that it will submit at the end of 1998, its first regular reports on each candidate's progress towards accession. In the case of Turkey, reports will be based on Article 28 of the Association Agreement and the conclusions of the Luxembourg Council. With this reference to Article 28 , it is understood that a report will be made, whether the Association has advanced far enough to justify envisaging full acceptance by Turkey of the obligations arising out of full membership.

Cardiff Council, having considered the Commission's "European Strategy to Prepare Turkey for Membership", according to the conclusions of the summit, declared that "taken as a package, this strategy provided the platform for developing our relationship on sound and evolutionary basis". Council also invited the Commission to carry forward this strategy including tabling of any proposals necessary for its effective implementation. Although this move was interpreted as an indication that "it was fully realized that a serious mistake was made in Luxembourg", this strategy still constituted a separate treatment for Turkey which constituted an open "discrimination" vis-a-vis the other candidates.

The European Council, also invited the Presidency, the Commission and Turkish authorities to pursue the objective of harmonising Turkey's legislation and practice with the acquis. This is similar to screening which is under progress with the countries included in the enlargement process. In terms of the implementation of the acquis communautaire, Turkey is already well advanced as thousands of pages of Community Regulations and Directives were adopted by Turkey over the last few years in relation with the customs union.

On July 22, 1998, Turkey presented her "Strategy for Developing Relations between Turkey and the EU" to the Commission and the Presidency, motivated by completing the shortcomings of the Commission proposals and enriching it in order to attain the intended target. After Luxembourg, Turkey aimed to enhance cooperation at least in trade and economic areas in a mutually beneficial manner so that trade and economic relations would not be affected in the way our political relations have suffered. On the other hand it was also made clear that the Customs Union would remain viable on its own as long as full membership, which constitutes the final objective of the Turkish Association, is firmly secured. 
Whereas the Commission proposals underlined the fact that their implementation "will depend on the financial resources available for Turkey", EU committments in the financial area have not been fulfilled. This, of course, has caused a serious diesequilibrium and indeed unfair competition in our relationship which is based on a balance of interests. In fact, in March 6,1995 , the EU had recognized that the Customs Union would create a new competitive situation for Turkey. The EU declared that "Turkey will need substantial financial resources, in particular long-term loans and technical assistance in order to adapt its industrial sector to the new competitive situation created by the Customs Union and improve its infrastructure linkage with the European Union, as well as to reduce the difference between its economy and that of the Community." However, in spite of its unconditional undertaking the EU has not fulfilled her obligations in this area and has left Turkey alone in handling this burden. Compared with the other candidate countries, this situation is certainly untenable.

Ever since the two Strategy documents were passed on to each other, three meetings were held with the Commission representatives in Ankara and Brussels. It was interesting to note that some of the areas covered in the Strategy talks did fall within the sphere of previous Association Council decisions or resolutions. These were "consultation mechanisms", "participation in technical committees", "macroeconomic dialogue", "institutional cooperation" and "participation in Community programmes". These were items that were to be developed irrespetive of the Strategy exists or not.

The Turkish participation in a number of expert committees certainly was crucial since Turkey is to implement most of the Community legislation. A request was made for taking part in 75 different Committees as they fall within the scope that is relevant to the framework of Turkey-EU relations. As Norway fully participates in more then two hundred committees initial Turkish request must be seen rather modest. In areas which are considered to be of direct relevance to the operation of the Customs Union, such as "technical barriers", "competition", "industrial and intellectual property law", "customs legislation" EU institutions must have extensive "prior consultations" with Turkey.

According to Association Agreement and Protocol, "freedom to provide services" and "the abolition of restrictions on establishment" have to be achieved.

The often repeated promises for alowing Turkey's participation in Community Programmes seem to be having not much progress.

Once the customs union was completed institutional cooperation became extremely important. Indeed, the Turkey-EC Association Council Resolution of 30 October 1995 envisaged Turkey's participation to Ministerial and high-level meetings of a sectoral nature related to the Customs Union but this was not realised either.

\section{Greek Obstructionism vis-a-vis EU policies towards Turkey}

Daphne Papahadjopoulos in a CEPS paper on Greek Foreign Policy refers to "Greek Obstructionism vis-a-vis EU policies towards Turkey". Whilst Papahadjopoulos reminds her readers the 1976 Commission Opinion on the Greek application for EC membership stating that "Greece's accession to the EC did not imply that the Community would become entangled in Greek-Turkish dispute", she observes "The policy of conditionality was applied 
by Greece in every single aspect of Turkey's relations with the EU and Greece has repeatedly used its veto power in the EC decision-making process to block the implementation of the fourth Financial Protocol toTurkey." According to Papahadjopoulos, in addition to Cyprus linkage to which from the very beginning Turkey has registered her strongest opposition, in the 1996 crisis in the Aegean, Greece has also been pressing for more support from the EU on its territorial dispute with Turkey. The same commentator says that "Greece has been institutionaly capable of upsetting EU-Turkish relations." At one stage "by repeatedly vetoing EU initiatives towards Turkey, Greece realized that it had pushed the conduct of EU-Turkish relations into unofficial channels where it had no influence." Indeed, "Greece's expressed willingness to act as a bridge between Europe and Turkey" is claimed to be "in line with an attempt to Europeanise foreign policy". 21

Thus, according to the same author, not only "Greece continues to veto the adoption of the financial regulation designed to accompany the Customs Union with Turkey" but also Greece "was largely responsible for the political conditions the Union has imposed on Turkey in connection with Turkey's participation in the European Conference." Another blackmail has been made clear "by signalling that Athens would delay the EU enlargement process if Brussels does not respect its commitment to integrate Cyprus." There is no doubt that once the EU surrendered to blackmail there was no end to further demands put forward by Greece. Therefore, today, the EU policy towards Turkey is being dictated by Greece according to her own interests and "a linkage has been created between major EU policies and Greek-Turkish disputes." Even the Greek author we have widely quoted notes that "the EU must ensure that Greece further pursues a more flexible approach towards Turkey in light of signals that its traditional obstructionism towards EU-Turkey relations may be receding". Accordingly, "the key to alleviating Greece's insecurity lies in a real settlement of the Greek-Turkish conflict." In order to achieve this "it is essential to change mentalities and bind the two countries together with common interests." While normally one would expect the EU expert from Greece to suggest that this could be achieved by Turkey's accession to the Union, her proposal focuses on the "EuroMediterranean Partnership" which provides a useful framework through which "socio-economic and cultural initiatives can be advanced across the shores of the Agean."

According to a British MP, "when Greece applied to join the EC it was decided by the Council on 24 June 1976 that the application would not affect relations between the Community and Turkey, and that rights under agreements between the EC and Turkey would be unaffected." Despite this decision he notes that "Greek representatives sparing no effort within all the institutions of the EU to damage relations with Turkey. It is a disgrace that on the European Parliament's committee on Turkey a quarter of the members are Greek." Michael Stephen also notes that "Greece is already a member of the EU but the human rights of the Turkish minority in Greece are consistently and seriously violated, with little comment from EU institutions."22

Ambassador Michael Lake, the Commission Representative in Ankara for seven years, in his "End of Post Report" notes that "Greek membership in the European Community upset the balance in the region which the previous Ministers had carefully maintained." According to Ambassador Lake, "the imbalance seriously undermines Western strategic and economic interests in the region." 
With regard to "Greek conditionality, " Ambassador Lake draws the attention of his Brussels headquarters to "a pattern of behaviour" which he has been aware since the Dublin summit of 1960 that "Greece will make agreements in principle, only to either disavow them or wreck them at the last minute introducing new conditions which Ministers often do not recognise as such in the wind-up to a long meeting." According to top Commission diplomat "this happened again at Luxembourg".

Ambassador Lake gives two examples of such Greek attitude : "Turks have at least twice met the conditions for Greece to litt its veto on financial cooperation; at first the condition was acceptance of a Council Declaration of July 15, 1996; the Turkish response was finally approved by both Greek and Turkish Ministers at a Barcelona Process Ministerial meeting at Malta in April last year-Greece disavowed the agreement an Association Council less than a week later, thereby unilaterally changing the position of the Council as a whole from one of acceptance to one of continuing veto, and subsequently in accepting (a letter from MFA Cem to Presidency MFA Poos) the Commission's proposals that disputes such as Imea/Kardak could be settled at the International Court of Justice. For Greece to maintain its veto again moved the goalposts, unilaterally changing the Council's perception of what it had previously agreed to. This has serious strategic and moral implications for the Union's credibility not only in Turkey but among our other partners."

Such reports by EU Ambassadors to their headquarters, should, of course, normally be secret. An ambassador after serving so many years in a post should be able to submit his or her conclusions to Brussels in complete confidence. In this case, it was not possible. Some Greek Commission officials leaked the report to the press, thereby forcing the Commission to make a statement that this report contained only the "personal" observations of the envoy and not neceessarily the "official position ". Whether it helps the Greek "national aims" to disclose the frustrations and forceful observations of a Commission Ambassador in Ankara is of course another matter. However, the number of scandals and crisis created by Greece has reached such proportions with no reaction or condemnation from her partners that there is no reason that Athens should hesitate to do anything she likes. The successor of Ambassador Lake probably would not dare to write anything which should be confidential in her end of post report.

After the capture of the most wanted PKK terrorist leader, who was hidden for ten days at the residence of the Greek Ambassador to Kenya, after being transported there by Greek secret service under the diplomatic immunity provided by Greek Ambassador, involvement of Greece in aiding and abetting the terrorist movement becoming so apparent, forced three Greek Ministers-including the Ministers of Foreign Affairs, Interior and Public Security- and the confirmation of all the existing evidence showing that Greece has beeen involved in PKK training, sheltering and provision of rockets and various other types of armaments to a Marxist separatist terrorist movement in Turkey, it would indeed be extremely difficult to justify "the Greek security deficit" which was the explanation given to Greek stance vis-a-vis Turkey within the EU system. Furthermore, the fact that the Greek Cypriot Administration provided a passport for the fugitive terrorist Ocalan was another contradiction as they call for cooperation with the Turkish Cypriots. 
As long as EU continues to give up to black mails and bows to threats coming from Greece, there does not seem to be any hope to improve the relations between Turkey and the EU. However, Ambassador Lake warns Brussels by the following note : "It is a question of our real interests. Are we ready to put the Greek Cypriot Republic of Cyprus before Turkey. Which is more important to our longterm strategic and economic interests ?" After referring to pipelines distributing oil and gas from the Caucasian-Caspian region to the rest of the world, Lake adds: "This whole area and its huge potential are of great interest to the EU and our major, indeed our only institutionalised ally in the region is Turkey." He also adds that Turkey is "the only muslim democracy in the world".

\section{Gestures or need to have the support of Turkey in such policies ?}

Turkey was invited to attend a meeting in Brussels, on 17 October 1998 on "Enlargement, Trade and the Multilateral System", together with all the other candidates. This was interpreted as an admission of the grave mistake made in Luxembourg. Some commentators noted that the Community institutions fully realize the mistake made in Luxembourg and try to give some positive signals as a gesture of good will. On the other hand, taking into account the full customs union between EU and Turkey, it was obvious that the subjects of this Ministerial meeting could not be properly treated without the participation of Turkey.

In addition to such few invitations, the Commission informed its staff that Turkey was also considered as a candidate country. In line with this inclination, and in compliance of Cardiff Summit Conclusions the Commission published a progress report about Turkey together with other candidates.

However, after being excluded from the Luxembourg process, the terminology used, ranging from "the applicant" to "the candidate", is not enough to erase the negative affirmation which had wide ranging repurcussions, not only in Turkey, but also in many Member States where it was realized that a serious and devastating mistake was made. The declaration of the European Christian Democratic Parties, made in Brussels in March, 1997, rejecting Turkey's accession on the basis of culture and religion, for example, was one of the several such negative affirmations which remains in the collective memory. After such extensive damage, with a series of exclusionary declarations, simply referring to Turkey as a "candidate" is of course not sufficient to bring the relations back to its normal track where it should be. In any case, the terms like "applicant" or "candidate" are descriptions of status which is gained by a simple application.

It is, indeed, high time to give a loud and clear signal that Turkey is included within "the present comprehensive, inclusive and ongoing process of enlargement" together with the ten Central and Eastern European countries, on the basis of the same criteria and that "it participates in the accession process on an equal footing" with all the supporting programmes like "enhanced pre-accession strategy."

It is obvious that a country like Turkey can not built its preparations for membership on such a vague, indefinite future perspective. A project of this magnitude can not be built on uncertain and slippery grounds when reference for membership is not given in a foreseeable future. 
Therefore, it is interesting to note that a draft proposal recently submitted in the European Parliament "invites the EU and Turkey, together with the Commission's assesment of Turkey's progress towards accession, to draw up a 'road map' consisting of detailed and time bound committments by both parties leading towards Turkey's accession to the Union". Report of Mr. Swoboda in fact underlines that there is an urgent need for a "road map" consisting of not only detailed but also "time bound commitments" towards Turkey's accession to the Union. After Luxembourg and associated developments, a vague and indefinite promise for an unforeseeable future cannot carry the weight of the customs union. It appears that both the Commission and many members of the European Parliament, take the view that Turkey should be given a clear and definite time-table. It is now up to the European Council to repair the damage done in Luxembourg. The Swoboda Report, although originally drafted with good intentions, became totally unacceptable after being amended by a coalition of various members of the EP from different groups under the leadership the Greek MEP s en masse- of all political groups leanings, with "heavily loaded" paragraphs concerning the extradition of Ocalan from Italy.

It was hoped that the German Presidency could inject some new momentum to TurkeyEU relations Thus an independent Greek daily, Eksusia, reporting on Turkey-EU relations, on 30 October 1998, pointed out the following : "Since Germany will take over the presidency of the Union, as of first of January, Bonn will give more importance to Turkey's path towards membership. Indeed, as Germany is expected to support Turkey's membership, it is believed that pressures on Greece will increase in order to lift its veto of the Turkish-EU Financial Protocol. "The Greek paper also adds that " Bonn's support for Turkey's membership request in the future is also highly likely."

The support given to Turkish accession to EU from the other side of the Atlantic, demonstrates that strategists in Washington have a longer prespective whereas some feel that European planning, or vision is very short term indeed. As it was pointed out by Mr. Strobe Talbott, of the US State Departement, Turkey has to be on the road leading to membership of the EU in order to interact beneficialiy and influentially with Europe :

"The European unity and integration will not be fully successful if a key European country is set uniquely alone and apart. Turkey has been a presence and influence in Europe for more than $\mathbf{4 0 0}$ years. For a host of reasons from its strategic position in Europe's southern tier to the vitality of its economy to the youthful demographics of its population-Turkey will continue to be a presence and influence in Europe in the future too. At stake here is more than the eligibility of one country for Europe's preeminent economic and political union. There are also implications for the nature and destiny of Europe itself. Throughout its history, Europe has been at its best when it has identified itself not in terms of artificial barriers -- a body of water here, a range of mountains there, a wall of concrete and barbed wire somewhere else-- but in terms of those universal values. One of those values is strength and unity in diversity, including religious and ethnic diversity. That's true for an individual country like the US or Turkey, and its true for the Euro-Atlantic Community as a whole which both the US and Turkey are a part. The debate within the EU over Turkey resonates with reference to 'culture' and 'civilization'. These words are often euphemisms for religion. There is a theory currently in 
vogue that the Cold War rivalry between communism and capitalism has been replaced by a global 'clash of civilizations. Turkey could and would continue to prove that religion in general and Islam in particular, do not constitute an impediment to modernization and integration. That is why it is of truly global importance that Turkey should be our partner, our Ally in multiple senses of that word, in fulfiling our common task in an age of growing global interdependence."

When we look at the figures provided by the Commission for all of the "twelve candidate countries" including Turkey, importance of Turkey becomes obvious : Turkey constitutes 35 $\%$ of the total GDP of the all 12 countries., covers $25 \%$ of trade and $60 \%$ of capital exports. According to World Bank, Turkey is the 17 th largest economy in the world today. If you look to the list of countries where the EU achieved trade surplus, Turkey moved from the seventeenth place in 1994 to seventh in 1995 and second in 1996. A quarter of the overall trade surplus the Community has achieved, vis-a-vis the rest of the world, in fact originates from Turkey. This means that whereas Turkey does not benefit from any financial support from the Community, it continues to support Community's economic growth and level of employment with this important trade deficit in favour of the Community.

Being the largest economy covering a large area from eastern Europe to the Balkans, the Black Sea Region to Central Asia and Middle East, Turkey, became a country which could not be ignored. While the Asian financial crises continue to effect many countries around the world together with the crises in Russia, which is of course an important trade partner of Turkey, Turkish economy proved to continue on its course without any serious negative consequences so far, thanks to its diversified economy, although some effects may be felt in the months to come.

Today, Turkey is fully integrated with the European integral market, European economic area, as well as the Euro-Atlantic defense and security systems. Consolidation of the customs union requires the strengthening of the institutional cooperation in every field. We must not forget that the customs union cannot be viable on its own as long as full membership, which constitutes the final objective of the association, is not defined according to a "road map" as described by Mr. Swoboda's report in the European Parliament, consisting of detailed and "time bound commitments" by both parties leading towards "Turkey's accession to the Union".

It is high time that the EU must review its policies towards Turkey and if it wishes to make a new start a series of irrevocable steps must be taken: First, Turkey must be included within the group of countries with full pre-accession strategy and accompanying programmes. A country which has established a customs union and implemented most of the acquis communautaire, thus fully undertaking most of the obligations arising from membership, may no longer be excluded from the enlargement process. Second of all, the proportions of the Financial Cooperation between Turkey and the EU must be reevaluated and upgraded to such amounts that a full customs union would require. Third, the so-called "pro-European" and "moderate" Greek Prime Minister has to make a big change in his policies towards Turkey. The 14 other Member States must make it clear to Athens that basing the whole Greeek foreign policy on the assumption that Turkey is a "danger", that Greece has a "security deficit" and for the sake of "vital national interests," everything must be made to blor 
Turkey's relations with the EU is no longer acceptable. EU must demonstrate clearly that its policy with Turkey may not be taken hostage by Greece.

Furthermore, it has already been made absolutely clear that the relations will suffer a very serious blow if Greece continues to shelter PKK terrorists, provides training facilities and armaments for terrorist activities in Turkey. Turkey has made it clear, not only to Syria, but also to Greece, a NATO ally, that these neighbouring countries under no circumstances should provide any direct or indirect support to the terrorist groups. (Syria has fully complied and forced Ocalan to leave the country and closed down the camps.) Such open hostility towards Turkey by Greek Government has already reached such a stage that it is bound to have extremely serious consequences and certainly does not provide an atmosphere for any improvement of the relations.

The existing problems between Greece and Turkey are not insurmountable. When both Greece and Turkey are members of the EU, it will be easier to establish the confidence between the two parties. The problems of the Agean Sea from the width of the territorial waters to continental shelf or Flight Information Region could easly be tackled in an atmosphere of cooperation and partnership. After all is not the EU a club where such differences have been overcomed between other Member States? Once Turkey joins the EU, the settlement on the island of Cyprus could also be achieved as the Turkish Cypriots would not have much to fear from being in the Union all alone without any kind of protection against the fanaticisms of the Greek Cypriots. It is gradually being realized by many observers that the current EU policy of "hi-jacking Cyprus" into EU under Greek black-mail tactics, in violation of the founding Treaties and the Constitution of the island is not going to lead to anywhere and in fact probably will completely alienate Turkey from EU. Furthermore, it is believed that the extracts taken from Clerides Memoirs as presented elsewhere in this journal, will illuminate certain basic problems with regard to the legal capacity "rechtsfahigkeit" and eligibility of that island for membership under founding Treaties and clearly establish that the regime with which the accession negotiations are being conducted do not have any constitutional legitimacy whatsoever.

\section{Security Aspects}

While Turkey is being systematically excluded from the EU, the fact that Western European Union (WEU) will be merging into the European Union framework brings further questions to be considered. The special status of Turkey within the WEU, according to some Member States and EU sources, would not be transformed to EU, as Turkey is not a member and thus she will also be excluded from the European defence structure.. Although this should be a more serious concern for the EU, it would not be feasible for non EU- NATO members to accept the fact that NATO assets could be used by the EU, where they are excluded from the decision making structure. According to experts, the WEU can never be a substitute to NATO and it is vital that the United States remains engaged in European defence

Although the cold war is over, East Germany no longer exists, the Warsaw Pact is dissolved and three of its former members have joined the NATO, there does not seem to be a long term strategic planning for the future of Europe. Certainly, the Russian Federation does not carry the same weight of the Soviet Union. Although, Russia still commands a large 
nuclear arsenal, its military structure seem to suffer from serious disorganization and its foreign policy is no longer driven by communist ideology. On the other hand, the new international "disorder" does not make the world a safer place. The events in former Yugoslavia demonstrated threats to peace in Europe. After Bosnia, where quarter of a million were killed and sixty thousand women raped, events in Kosova where the allies did not wish to engage land forces further demonstrated the weaknesses in the security infrastructure of Europe. The role played by a EU member State supporting the Belgrade Government also raised question marks as to the common foreign and security policy. Whereas experts claim that there are many future trouble spots ranging from Balkans, Eastern Europe, Russia, Caucasus to Middle East and North Africa, a "security concept" for the EU or if you like, United States of Europe, so far seems to be neglected.

In this connection, would that be feasible for the EU to have a security planning without Turkey? Whereas the signals from EU and most of the Member States indicate that the new Europe may effort to exclude Turkey from defence of Europe, the United States thinks otherwise. Naturally, this is a decision for the EU Member States to make.

Defence and security experts claim that threats to Europe's political and economic interests arise today from instability in other regions of the world. Arguably the most important of these is the Middle East and North Africa. Turkey, according to experts in strategic planning, on the south-eastern flank of NATO, has an extremely important jeo-strategic location, in a position to control access to the Black Sea ports and the transport of Caspian and Central Asian oil and gas to world markets by pipeline across Anatolia to Ceyhan on its Mediterranean coast. They add that Turkey has for half a century been a member of NATO, making a major contribution to defence of Europe, (thus enabling the former Warsaw Pact countries to be freed from Soviet hegemony), allocated substantial financial resources for her defence budget which had its economic consequences. According to Michael Stephen, a former member of the British Parliament "the history of the post-war world would have been quite different if the Turkish people had not wholeheartedly identified themselves with Western interests." Turkey shares a border with Syria, Iraq, Iran, Armenia, through Nahcevan- Azerbaycan, Georgia and has made a vital contribution to the Gulf War and subsequent efforts against the regime in Iraq. The oil pipeline from Kerkuk to Yumurtalik in Turkey was closed by the Turkish Government during the Gulf war, at a huge cost to Turkish economy, and has remained partially closed in support of UN sanctions. The whole basis of NATO's position in that region would be undermined if Turkey reduced or withdrew its support. According to Stephen, "present attitudes in Europe are contributing gradually to the alienation of Turkey, to the detriment of western security interests and of European companies who could benefit from Turkish makets and infrastructure projects." 23

\section{Some Observations on the Arguments for EU Membership for Cyprus}

Whereas it is clear that accession of Cyprus before Turkey's Membership of the EU will be a flagrant violation of the founding Treaties and the Constitution of the island, the introduction of a new element, i.e. EU membership, has totally changed the parameters on which the bicommunal and bi-zonal federation was based. Indeed, the protection to be gained from bicommunality and bi-regional character of the would be federal state will disappear when that republic joins the EU before Turkey does. 
When our friends, from various EU institutions, Member States, or from the U.S., suggest that the best way to solve the Cyprus problem is EU membership on the basis of a bicommunal, bi-zonal federation, they seem to disregard the supra-national characteristics of the Union.

In a final settlement of the Cyprus problem, Turkish Cypriots would no doubt request guarantees and safeguards in the Constitution that would ensure equal voice in the government. Naturally, when one looks at the 1960 Constitution, the mechanism provided therein will be qualified as "functional federation".

In fact, the 1960 Constitution and the Zurich and London Agreements, created a "state of affairs" not only between Turkish and Greek Cypriots but also between the two motherland countries, Greece and Turkey. The Constitution, with a Greek President elected only by the Greek Cypriots and a Vice President elected only by the Turkish Cypriots, a Council of Ministers with 3 Turkish and 7 Greek ministers (the Minister of Foreign Affairs and Defence to be appointed by the Turkish side; House of Representatives, Public Administration, Security Forces to be formed in line with $40-60$ ratio between the two communities; each community having its own "Communal Chambers" and separate municipalities in five big towns for the Turkish Cypriots. These "checks and balances" in the Constitution and in the Treaties establishing an independent Republic of Cyprus based on the premises that this delicate balance or equilibrium, if you will, between the two sides should not be tilted in favour of the one or the other side, in its international relations, especially through memberships of international organisations. The drafters of the Constitution realised that if this "Republic of Cyprus" joins an international organisation in which only Greece or Turkey is a member, the carefully drafted "balance" between the two communities, all the provisions specifically built in the Constitution for the protection of the Turkish community would change in favour of the other side.

It is interesting to note that the Zurich and London Agreements were negotiated in the first few months of 1959 and finalised in July 1959. Incidentally, at the same time both Athens and Ankara applied to EEC for associate membership. One does not guess and wonder which international organisation they had in mind when they provided that Cyprus cannot join. Certainly, membership in a standard type of international organisation like the World Health Organisation or the Universal Postal Union was not what they had in mind. The term supranational was not used that much those days, with the exception of some scholarly work. in fact, until the famous Van Gend de Loos case in 1962 (case 26/62; 1963 CMLR 105) the supra-national character of the community was somewhat neglected in official literature.

Although Commission officials may not recognise the right of veto of Turkish Cypriots in foreign affairs, Mr. Clerides in his memoirs explains this veto power of the Turkish Cypriots under the Constitution of Cyprus: "Clearly, the Vice President would have acted within his constitutional rights if he had decided to use the veto the Constitution gave him on matters of foreign policy"24.

When Turkish Cypriots consider membership in the EU either they will study the impact of accession as an independent state (TRNC) and its implications for them as to the timing 
whether it is before or after Turkey's accession and try to analyse their position in the institutional framework; or they will try to see what their position will be in a "federal Cyprus" under the banner of Turkish federated State. However, after weighing the position of an independent TRNC as a full member of the EU, all alone on its own, before Turkey's accession and the difficulties it will face as a state with only one vote, if at all, after the institutional reform and changes in the decision-making system, an evaluation of being in EU under the umbrella of "federal Cyprus" would certainly result in a more dramatic conclusion. The Greek Cypriot state of Southern Cyprus would not be objecting too strongly if representation of mini states or micro states is restricted in the Commission, in the Council and in the European Parliament (certainly, in a European Parliament with maximum 750 seats countries like Luxembourg will not be able to send 6 MEP's. The most they can imagine is 2 in order to allow maybe one opposition representative - but probably it will only be one MEP). Even if the Turkish Republic of Northern Cyprus is admitted as a full Member State, its representation in EU institutions will be less than a minimal level. The Greek Cypriot Republic of Southern Cyprus might not mind such a minimal representation or not being represented at all for mini states or smaller member States, as Greece is already a Member State and represented in all the institutions and performed extremely well in recent years as far as representing Greek Cypriot interests in the EU with the use of veto itself or the threat of it.

When bi-communal, bi-zonal federation "BCBZF" was agreed between the two sides, (between Mr. Denktash and Mr. Makarios back in 1977), membership of the EU was not in any way under consideration. It was, something which was unthinkable. "Bi-communal, bi-zonal federation" was accepted as the main principles of the future settlement when it was clear that this "Federal Republic" was not going to join any supra-national institution like the EU. The previous ban under the 1960 Treaties, the limitation of sovereignty on this matter naturally would continue. The EU did not realise that by introducing the issue of membership in such a supra-national organisation where member states transfer some of their sovereign powers to Community institutions, the parameters on which the solution was based have completely been changed. Indeed, when "BCBZF" was envisaged it was based on the fact that Cyprus would be independent so that the delicate balance between two sides would not be affected. By introducing the EU membership issue, the whole set-up, all the parameters of a possible solution, the basic principles on which the federation was based have changed.

An indrependent Federal Cyprus based

on bi-communal/bi-zonal principles

and equality of both sides-with firm
First case: Cyprus is not joining

any international or supra-national

organisation

The moment this independent stat joins a

supra-national body like the EU, the whole

premises on which such a settlement was based, change. 
That is why in a book I published earlier. ${ }^{25}$ I have argued that the solution under the new circumstances has to transform from federation into confederation - but membership in the EU only possible after Turkey's accession. A detailed analysis of the status of the TRNC as a Member State of its own, its representation in EU institutions, the balance of power, etc. has to be examined carefully.

Furthermore, the following question must also be answered: whereas the EU is going through an institutional reform process, whereby the composition of EU institutions (Commission, Council, EP, ECJ) and their powers, rules concerning voting requirements, etc. are under a comprehensive review, so that nobody really knows the exact status and framework the EU will take before accession, how can Turkish Cypriots envisage a constitutional framework in Cyprus before the complete picture of the EU becomes definitely defined? 26

Although it is not possible to examine every aspect of this representation, be that as it may, either as an independent Turkish Cypriot State or under a federal umbrella being an equal partner of the state concerned, I can mention a few issues which come to one's mind at first sight.

Officials of some of the Union's institutions, (among others, the Head of Commission Representation in Nicosia, Mr. Giles Annouil, who was accredited to the Greek Cypriot Administration) have been actively involved in efforts to convince Turkish Cypriots that "membership would enable them to be represented in important Community institutions", or "that they would not any more need the guarantee of Turkey because the European Court of Justice would be their most efficient guarantee and security", etc.

If we assume that, indeed, a bi-communal, bi-zonal federation has been established and this "Federal Republic of Cyprus" has become a member of the European Union, will the Turkish Cypriot Federated State be represented in the important decision-making institutions of the Union? The answer given by Commission representatives is that the "important decision-making institutions" that the Turkish Cypriots will be represented is the "Committee of the Regions" and they may, if they are lucky, take part in this Committee as a "region" of a Member State. For those who may wish to evaluate the importance of being represented in this "important" decision making institution of the Union, I wish to refer to Article 198a (Art. 263 in the consolidated text) of the Treaty Establishing the Community which provides that it is "A Committee consisting of representatives of regional and local bodies" and it has only an "advisory status" 27.

At the present time when the decision-making procedure and the representation of member states in the Community Institutions are being reviewed, before the next enlargement which would result with possibly 20 to 30 Member States, there are some reform proposals on the table:

- The Commission, already composed of 20 members must be reduced in size, possibly to a college of only 10 Commissioners, which would mean that larger Member States would not nominate 2 Commissioners and also that not at all the Member States send somebody to this executive body. Some scenarios under discussion suggest that mini states should not be 
nominating their citizens to this important institution which is considered as the guardian of the Treaties. In a Union of say 25-30 Member States even if the big states' right to nominate 2 Commissioners will be reduced to one person each (Germany, France, Italy, UK and Spain) it is not expected that countries like Malta, Estonia, Latvia, Cyprus and even Slovenia would be represented in the Commission. If it is decided that the Commission would be reduced in size in order to have an effective mechanism, in addition to Luxembourg, relatively smaller countries like Ireland, Denmark and maybe even some bigger members may be nominating their own candidates to the Commission on a rotating basis.

- As the real legislative power of the Union is exercised by the Council in co-operation with the European Parliament and Commission, representation in the Council by this Federal State will be important: as the supra-national characteristics of the EU institutions are important, let us even assume that a solution of the Cyprus problem has been found in such a way that both Republics on the island join the EU as independent Member States. The Turkish Republic of Northern Cyprus with a population of 200.000 and the Greek Cypriot Republic with 600.000 . Today, larger member States have 10 votes in the Council. The smallest country, Luxembourg, in this "weighted majority" weighs quite "heavy" and has 2 votes with a population of a mere 340.000 , whereas Germany with 87 million has only 10 . The total number of votes today adds up to 87 for the 15 Member States. In order to have a decision to be adopted by qualified majority, the minimum number of votes required is 62 . (Thus the "blocking minority" is 26 votes). Before the last enlargement, the total number of votes was 76 and for an Action which required "qualified majority" a minimum of 54 votes were necessary . $54 / 76$ after enlargement became $62 / 87$. Thus, the blocking minority vote increased from 23 to 26 which means the number of votes required to stop a legislative act being adopted increased from 23 to 26 .

\begin{tabular}{|c|c|}
\hline \multicolumn{2}{|c|}{ Number of Votes (And Member States) Required in order to reach Qualified Majority } \\
\hline $\begin{array}{l}\text { Before } 1995 \text { - } \\
12 \text { Member States }\end{array}$ & $\begin{array}{l}\text { After } 1995 \text { - } \\
15 \text { Member States }\end{array}$ \\
\hline Total votes: 76 ; required 54 (54/76) & Total votes: 87 ; required 62 (62/87) Total population: 371 \\
\hline Total population: 338 million & million \\
\hline Number of Member States in order to reach & Number of Member States in order to reach 62 votes $/ E 8$ \\
\hline 54AE7 Member States (D+F+1+UK+SP+IRE+DK) & Member States $(\mathrm{D}+\mathrm{F}+\mathrm{l}+\mathrm{UK}+\mathrm{SP}+\mathrm{PORT}+\mathrm{AUST}+\mathrm{GR})$ \\
\hline Total population of this $7: 254 \mathrm{~m}$. & Total population of this $8: 323 \mathrm{~m}$. \\
\hline Ratios: $7 / 12 ; 54 / 76 ; 254 \mathrm{~m} / 338 \mathrm{~m}$. & Ratios: $8 / 15 ; 62 / 87 ; 323 \mathrm{~m} / 371 \mathrm{~m}$. \\
\hline
\end{tabular}

Source: Eurostat 1995 and EUROP

\section{Number of Votes (And Member States) Required in order to reach "Blocking Minority"}

Before 1995 .

\section{Member States}

Six small Member States representing $12 \%$ of the total population could gather 23 votes in order to prevent a decision $(B+D K+G R+I R L+L U X+P O R)$ Total population of these Member States: 39 million

Total EU population: $338 \mathrm{~m}$.

\section{After 1995 .}

15 Member States

Seven small Member States is required to reach the blocking vote of $26(B+D K+G R+I R L+L U X+N L+F I N)$

Total population required: 50 million

Total EU population: $371 \mathrm{~m}$.

ratios: $7 / 15 ; 26 / 87 ; 50 \mathrm{~m} . / 371 \mathrm{~m}$.

ratios: $6 / 12 ; 23 / 76 ; 39 \mathrm{~m}, 338 \mathrm{~m}$. 
It will be recalled that the Government of the UK strongly opposed to the increase of blocking minority votes from 23 to 26 . Although with the increase of the number of member States from 12 to 15 , the number of total votes also increased to 87 and the qualified majority changed from $54 / 76$ to $62 / 87$. It was thus normal that the minimum number of votes to block a decision to be taken would rise to 26 from 23 but the UK government which is one of the "Big States" with the maximum 10 votes was resisting the increase of blocking minority from 23 to 26 . Whereas you could have blocked a decision with 23 votes, now you need 26. Britain resisted this change for three months and only agreed with the Yanya (loninina) Compromise whereby it was accepted that once 62 votes is reached, the decision will not be taken immediately but efforts will continue to reach 65 . The Council will have to do everything in its power to reach 65 while respecting the time limit provided in Article 189 b,c 28

If for a big member State like the UK which has 10 votes, the increase of the number of minimum votes to block a decision by a qualified majority from 23 to 26 , is considered against its "vital national interest", can you imagine the position of a small Member State like the Turkish Republic of Northern Cyprus which should probably have one vote, if any, in the decision-making process, together with the Greek Cypriot republic, probably also one vote but an important factor would be Greece being represented in the Council with 5 votes. And furthermore, Greece is fully represented in all EU institutions.

In a recent book ${ }^{29}$,Middlemans underlines that Member States need to establish coalitions in order to have a decision. A big country even with ten votes needs a lot of support both for the adoption of a legislative act and for blocking them: "It is barely open, even to small states, to play the field at will: genuine national interest in common". Even if the Turkish Republic of Northern Cyprus is admitted as a full member into the EU before Turkey's accession, taking into consideration the performance of Athens since 1981 (from Macedonia crisis to imposing of total blockage to Turkey's Relations with the EU) with a second Hellenic republic sitting together on the table, how can TRNC defend her interests or with which Member States could she try to establish coalitions?

Where would be such a "minimum genuine national interest in common" for the Turkish Cyprus Republic, which would allow such coalitions?

This also clearly demonstrates the importance of Treaty provisions on Cyprus which do not allow Cyprus to join an international organisation where both Greece and Turkey are not members at the same time.

Mr. Jean-Louis Bourlanges, after serving as an MEP and as a top French bureaucrat makes the following observation: "At the present time, there is a growing mistrust between the small and large Member States. This is partly because the EU's current decision-making system has evolved under the treaties. Furthermore, the balance of power between the member States is by nature unstable..$^{30}$

It is clear that the provisions which forbid Cyprus to join an international organisation where both motherland countries (Turkey and Greece) are not members, were carefully thought of Articles with fully justified reasons. And of course, this ban on Cypriot membership was provided even when the Turkish Cypriot community fully participated in the functional 
federative system under the 1960 Constitution, that is to say Turkish Cypriot Vice President, three Turkish Ministers in office, 60-40 representations in House of Representatives and so on. Even if the 1960 Constitution was fully respected today with complete participation of the Turkish side in this "partnership", the Republic of Cyprus does not have legal capacity (rechtstähigkeit) to join an international organisation unless both Greece and Turkey are full members.

Otherwise, the careful balance established in the Constitution, the specific safeguards, the delicate "checks and balances" all carefully embodied in the Constitution, would be totally destroyed as the balance would tilt in favour of that side whose "motherland", is full member in an organisation, whereas the other side is totally excluded. It is for that reason that the Constitution and the Treaties establishing the Republic of Cyprus as an independent state, restricted Cypriot sovereignty, and provided that it cannot join such an international organisation.

This limitation of sovereignty which is provided not only in the Constitution but also in the Treaty of Guarantee, do not give Cyprus the legal capacity to join such an international organisation. And this restriction was foreseen even when everything in Cyprus would be functioning completely in accordance with its Constitution in perfect harmony. Today, since 1963, Greek Cypriots do not follow the Constitution and therefore the present Greek Cypriot regime has no constitutional legitimacy as they have pushed the Turks outside the Government in December 1963. The fact that, since March 1964 Decision of the UN Security Council, which refers to the Greek Cypriot Administration on the island as "the Government", many countries recognise that side as the Government, does not change the fact that it is an unconstitutional regime, it does not have a legitimate constitution.

With the implementation of the four basic freedoms within the EU, there would be problems in the sense that the security and protection hoped to be gained by "bi-zonality" could disappear taking into consideration the tragic experiences of the past. The argument that some long-term derogations could be provided in the accession treaty so that Greeks would not intrude into the Turkish zone sounds interesting at first sight. Examples given for such derogations includes the ban for German citizens acquisition of property in some Danish islands and some special status for Aland Islands between Sweden and Finland. Since these derogations would be in the accession treaty, any action against them could be taken to the Court of Justice.

Here the question would be the following: Who can bring an action in the Court of Justice? Would a subdivision of a federal state bring an action under Article 170? This article provides that "a Member State" which considers that "another member State has failed to fulfil an obligation under this Treaty may bring the matter before the Court of Justice". Could the Turkish Federated State of Cyprus bring an action against federal Cyprus or the Greek Federated State? No, these are internal constitutional matters which can only be settled in the national Constitutional Court. Luxembourg Court cannot interfere in internal constitutional matters. Having the experience of the Supreme Constitutional Court of Cyprus between 1960 1963, resulting with the resignation of Chief Justice Professor Forstoff is not encouraging at all. 
Matters may be referred to the Court under Article 177 of the Treaty as "preliminary ruling procedure" but only if the local court decides to do so. Although the highest courts against whose decisions there is no appeal, must refer the matter to ECJ in Luxembourg there have been some examples of violation of this vital Treaty rule without any remedy (Boletin Oficial del estado, 15.3.1991, case 28/1991). The time required for a preliminary ruling is around 25 months, and examples of non-compliance by Member States cover a lot of pages in the European press ${ }^{31}$.

In order to have the Court of Justice as a guarantor of provisions, derogations, etc., the Turkish side (TRNC) must be admitted as a full member state which can bring an action in the Court on its own under Article 170. Otherwise, avenues open for a "federated state" within a Member State is extremely restricted and in a conflicting atmosphere, which is not unexpected taking into consideration the fifty years of violent clashes, such a "federated state" would be "locked in" without any other avenues being available.

I wonder whether Aland Islands between Finland and Sweden, two countries with no serious conflict for several centuries occurred, could be an example for Cyprus? The new provision of the Amsterdam Treaty with the threat of suspension of "certain rights deriving from the application of this Treaty" to the Member State where serious and persistent breach of human rights, liberty, democracy, on fundamental freedoms occur, will not be a threat to Federal Cyprus Republic, although this Member State will not have a right to veto such a decision, nothing in the new Article 7 (Article F.1.) prevents a blockage by Greece, another Member State.

Thus, from whichever angle one looks into this matter, the Treaty provisions of 1960 which do not allow Cyprus to join an international organisation unless both Greece and Turkey are full members, becomes not only more and more understandable but also extremely realistic and fully justified.

Those who suggest that membership of Cyprus in the EU will solve all the problems, may be unaware of the tensions that exist between Member States of the Union today, even if they do not have a background of violent conflict as was the case between Greek and Turkish Cypriots over the last four decades.

Keith Middlemans, compares the struggle between Member States with Prophet Isaiah's description:

"According to the prophet Isaiah, Joseph and the angel wrestled all night and still vied with each other when the dawn broke. In the sense that competition continues within the Community despite the new title European Union, the image applies. But as far as member States are concerned, the struggle has several faces. They compete generally among themselves according to the dictates of national self-interest, but also in groups of varying size, on lines set by affinity or choice" (p.331).

One should read the following remarks of Middlemans while envisaging Turkish Cypriots' accession before Turkey joins the EU: 
"Unending contests take place over boundaries and competencies. If it had not been so, the 1960's federalists' dreams might have been more successful... Personalities and alignments, national perceptions of interests, define what is to be in the group interest and when Member States and the Commission will find themselves on the same side. It is a political market place..." (p.339).

MEP Mr. Bourlanges points out that "successful enlargement of the EU calls for a clearer division between the representation and operational functions of the Member States. At present, each EU institution is made up of representatives from Member States who share day-to-day management responsibilities. This structure, which met the needs of the early members of the European Community, would be inappropriate in a Union of up to 30 members".

Professor Martin Seidel, who is a top official in Bonn makes the following observations (as if he were talking about Turkish Cypriots joining the EU as a separate independent state, but not under a federal umbrella) in the Philip Morris Institute Conference: "...the citizens of the Union, despite electing their representatives to the European Parliament, have only very limited extent direct relationship with the Union and its institutions. The EU is run by and for its Member States, and it derives its legitimacy from them... The EU is a Community of individual and separate states... Within the context of the first pillar, the EU does not have the regulatory and legislative authority that amounts to genuine sovereign power. But this power is derived from the Member States themselves and not directly from citizens. Because of its particular structure as a community of states, only the member States exercise Community sovereignty".

Mr. George Robertson, when he was shadow Scottish Minister of State made the following remarks in 1996, which may have some relevance to the importance of continuation of the sovereign state of the Turkish Republic of Northern Cyprus: "National identity is still very important. Talk of a Europe of Regions is something for the century after next. For the time being, the nation state and its relationship with the suprastatal Community architecture at the centre remains the key problem for the EU" (p.62).

Foreign Policy Spokesman of the Czech Christian democratic Party, Mr. Lobkowicz, asks the following question: "What does equal representation of members mean in an organisation with as complex an institutional structure as the EU?". Here is how he gives his reply as if he had the TRNC in mind: "In my opinion, the most important aspect of equality for Member States is their participation in the decision-making process, and their ability to be represented politically and to co-decide."32

An experienced MEP from Germany, Mr. Brok, notes that "few citizens really understand the way the Union works. Most view the EU's political and administrative structure as a conglomerate of institutions and decision-making procedures whose functioning and interaction is barely comprehensible, even to experts... Because the citizens do not understand the way the $E U$ works, they feel they have very little influence on European affairs, and their views therefore have little significance". 
How would a citizen of the Turkish Republic of Northern Cyprus evaluate his or her position in the EU under a federal umbrella when he continues to read Mr. Brok's remarks: "The EU's current decision-making procedures are so manifold, so complicated and so impenetrable that the only way to make them transparent is to reform them. Shrinking from such reform would be dangerous... The average citizen is not speaking out because the EU's institutional structures are too complicated to comprehend and its decision-making procedures are too labyrinthian to follow".

How would a small federated state, a land, or a region, if you will, under a federal structure, hope to protect its own interests, first in the federation itself and then within the EU? Mr. Brok says "At present, the EU's procedures are too complex to be suitable for even media coverage. This leads to little coherent information appearing during the various stages of legislation. Since information is scarce, the average citizen cannot follow the EU legislative process as he does national affairs. There is a void which is filled by ignorance. Ignorance breeds fear and fear can be stirred by populists and opponents of European integration so that it becomes rejection not only of a single proposal, but of the EU as a whole".

How would the Turkish Cypriot leadership operate in a federal structure vis-à-vis Community legislation, taking into consideration the following comments of Herr Brok: "When public contempt focuses on over-regulation, over-harmonisation and autocracy from Brussels, national politicians often conceal the fact that these directives and regulations are not the prerogative of a super-bureaucracy in Brussels, but do in fact, represent the powers of the Council of Ministers, which, of course, is composed of government representatives of each of the 15 member States". (Under a federal Cyprus, Turkish Cypriot interests would hardly have a sympathetic ear in Brussels, before Turkey becomes a full member).

As if all of the above were not enough, let us look at the comments of the Swedish Minister of Foreign Affairs: "Secrecy is one of the EU's weak points. The system of secret 'declarations', which limit or lay down conditions for the decisions taken by the Council of Ministers, has no justification". But in such a system when in the Council of Ministers you have a Minister from Greece plus a representative of Federal Cyprus - most likely a Greek - how can you feel as a small Community? A baby sheep in a group of wolves?

What about the argument focusing on subsidiarity? Proponents of EU membership present it as a guarantee for Turkish Cypriots. Does this make sense? Mr. Paddy Ashtown, a leading British politician says, in his view "the whole question of federalism hinges on defining exactly what powers of the federal institutions are, and what the rights and responsibilities of the other components of government - local, regional and national - should be. As long as we hide behind a fuzzy word like subsidiarity, the public will be confused and the national governments will be frightened". If national governments will be frightened what about a federated entity as they wish to push TRNC into the EU as a sub-entity?

Professors Dashwood and Wyatt, on the other hand, ask "whether the principle of subsidiarity is justiciable? The better view is, perhaps, that the content of the principle is too imprecise for it to constitute, on its own, grounds for reviewing the validity of an act of the Council or the Commission". ${ }^{33}$ Of course, we must remember, under Article 170, it is only 
"Member States" which can bring an action in the Court of Justice, not sub-divisions of a Member State.

Paddy Ashtown sounds like he is answering a question concerning the Turkish Republic of Northern Cyprus when he submits the following: "Who will determine the principles of decentralisation or subsidiarity should apply? This is the central question, and we have ducked it. We have hidden behind the word subsidiarity, yet nobody knows what it means. This is one of the reasons why people are frightened of Europe. We must come up with a clear and understandable definition of the separation of powers between federal and national institutions. No federal structure can work unless we do that". In the case of Cyprus, this balance has to be achieved first in a federal state and secondly within the EU another federal and supra-national structure. The task is not easy. Here is how Mr. Paddy Ashtown evaluates the issues: "The laws the Council passes have a profound effect on people's lives. It is simply unacceptable for these decisions to be taken by the Council in secret and for the fallout to be blamed on bureaucrats in the Commission". Ashtown also refers to "... the way Council horsetrading has gone, particularly over issues like Bosnia, has led to things that have been manifestly inappropriate and wrong". 34

A former Minister of Foreign Affairs of Italy made the following comments in a Brussels seminar some time ago: "During a recent visit to Finland I raised the issue, with the local authorities, of the Council of Ministers possibly becoming excessively large in the future. They replied by reminding me of their history of relative exclusion from European political processes and the intricacies of Community policy. In this, I sensed their fear of becoming a small, remote German province" (In a larger EU can all members be equal?, Brussels, 1996, p.27).

In a full Member state, with a population of 5 million, represented in the Council of Ministers with 3 votes, with a right to nominate a Commissioner, with a judge at the Court of Justice, with 16 members in the European Parliament, with enough number of functionaries in the Commission within the quotas, with the right to bring action in the Court of Justice, with all other rights and privileges of membership, "fears of becoming a small, remote German province", taking into consideration the actual distance between the two countries and the fact that there is not a substantial German community in Finland, even if there were - there is no history of hatred or animosity between the two; just imagine what the situation of Turkish Cypriots would be in a so-called federal state, facing Greeks three times their size and presence, with extreme hatred and desires of "revenge" from the Greek side, with full-scale military manoeuvres being staged, only last week, (with the full participation of the Greek Air Force F.16 fighter jets taking part in military games, thereby violating airspace of the Turkish Republic of Northern Cyprus, ending with the declaration that the areas in the north were cleaned from Turkish Cypriots) membership in the EU would solve all problems - and they would not feel like a province of Greece, who actually instigated a coup d'Etat for the purpose of uniting Cyprus to Greece, with thousands of mainland Greek soldiers in Cyprus fighting to this end.

A top Commission official and distinguished legal scholar, Prof. P.S.R.F. Mathijsen, well known with his informative and excellent book A Guide to European Union Law, which made its sixth edition in 1995, after many years of experience in Community institutions, broadly 
describes the functions and shortcomings of the Community institutions so well that for the Government of the Turkish Republic of Northern Cyprus, it does constitute a perfect "Guide" when membership in the EU becomes a subject of discussion and evaluations:

- "The Council tends to act as an intergovernmental conference where every member fights for his country's interests".

- "The Commission, which besides its overwhelming administrative task must also fulfil a political function, is bound to accept compromises in the implementation of Community legislation by the Member States".

- Parliament does not have all the required powers to exercise an effective democratic control.

- "There is the statement that the Community is 'based on the rule of law', in other words, the law prevails over all other considerations. The basic rule is not always well perceived by the Member states and there lies, therefore, a particular task for the Courts in ensuring the application of the law" (p. 83).

It is clear that EU membership of Cyprus before Turkey's accession, whether it is under federation, confederation or independent Turkish Republic of Northern Cyprus being admitted as a full member, because of the supranational character of the EU and with the specific balance as explained above is not acceptable and fully justifies the provisions of the Treaties establishing Cyprus as an independent state and constitution, which limit the legal capacity (rechtstähigkeit) of Cyprus to join an international organisation, unless both motherland countries are full members. After all, former EU Ambassador in Turkey, Mr. Michael Lake, after completing a seven-year term in Ankara, wrote in his "End of Post report" that "Greek membership of the EC upset the balance in the region which previous ministers had carefully maintained. The imbalance seriously undermines western strategic and economic interests in the region". He adds: "The EU is driving Turkey into irrational behaviour on Cyprus". Turkey is forcing the EU to negotiate only with the Greek Cypriots and to confront the EU with membership of the Greek Cypriots. My personal view is that it is unacceptable to be negotiating adhesion with a government which plans to introduce Russian missiles aimed at one of our allies. Are we ready to put the Greek Cypriot Republic of Cyprus before Turkey? Which is more important to our long-term strategic and economic interests? "The talks under the aegis of UNSC were balanced: both sides were recognised as equal communities. The proposed accession negotiations as yet make no provision for any equality of status for Northern Cyprus".

\section{Conclusions}

An important aspect of the Turkish Association is of course the "social chapter" which has not been touched since early 1980 s. It is highly unfortunate for a Community, which claims to respect international law and the rule of law, that the Decisions of the Association Council dating back to 1980 concerning the social security rights of Turkish workers have still not been implemented. After Demirel and Sevince Judgments of the European Court of Justice, more than a dozen cases concerning Turkish citizens were referred to Luxembourg. Whereas these judgments underlined the provisions of the Decisions of the Association Council which have 
direct effect, the Council of Ministers has still not acted on the Draft Regulation ${ }^{35}$ submitted by the Commission back in 1983. Under these circumstances, in order to benefit from the most fundamental human rights- the social security rights-, citizens of Turkey are forced to bring cases in the national courts of Member States and hope to convince the judge to refer the case to Luxembourg, which prolongs the proceedings (at least eighteen to twenty-four months) and a lot of lawyers fees and additional legal expenses. Due to lack of space, the social aspects of this Association will be discussed in a separate paper. Therefore, we only wished to mention this matter in passing. There are of course a number of other fundamental problems ranging from lack of consultations in forming common commercial policy to "decision making" which must be extensively debated. If the EU is conducting negotiations for a free trade (or for that matter any other type of) agreement with a country in the region (with which Turkey has extensive trade relations) and fails to consult and inform its sixth largest trade partner which has established a customs union with EU (therefore, has to implement the Common Customs Tariff and the Common Commercial Policy) in violation of Decision concerning the Customs Union.

In this special issue presented to Professor Oğuz, a veteran of European movement, it must be underlined that although both sides may be sharing some of the blame for the state of affairs, the general feeling in Turkey is that in its relations with Turkey, the European Union has, unfortunately, betrayed its own European ideals and according to some reflects the "crusaders" mentality towards Turkey, In fact, when the European Union returns to its basic European ideals principles and abandons its discriminatory policies towards Turkey the relations will no doubt will continue on its natural path. The fact that a very recent opinion poll held in May, 1999 confirms that over $82 \%$ of Turkish public continue to believe that Turkey should join the European Union, clearly demonstrates that the overwhelming majority of citizens of Turkey is not deterred by prejudiced attitudes of the EU.

\section{Endnotes}

1- Turkey made an explicit choice: she could opt out for a simple free-trade agreement, but, instead of EFTA, the Turkish Government preferred to line the original six which aimed at a political union at the end.

\section{2- O.J. L217, 29.12.1964. English version appears in O.J. C113, 24.12.1973.}

3- Turkey-EEC Relations, 1963-1977, Ankara, 1977 "produced under the auspices of the EC Commission Office in Ankara" according to Gianpaolo Pappa, Head of the EC Office in Ankara as stated in his introduction to the book.

4- ibid p.3.

5- Council Regulation (EEC) No.2760/72; O.J. L293, 29.12.1972.

6- It is interesting to note that on the same day the Association Agreement was signed, both heads of delegations exchanged letters upon the request of the Turkish side that "Community, having regard to Articles 4 and 12 of the Agreement of Asociation, agrees that the Council of Association may, once the preparatory stage has begun, investigate labour problems occuring in Turkey". This may be a sign that parties wanted to be alert to structural 
problems that may arise as Turkey gradually reduces her customs tariffs.

7- Communique de presse conjoint publie a l'occasion de la signature a Bruxelles, le 23 novembre a970, d'un Protocole additionale regissant la phase transitoire de l'Accord d'Assocation et d'un nouveau Protocole financier. (Association CEE-Turquie, CEE-TR 49/70).

8- Fraser Cameron: "EU-Turkey Relations, Proceedings of a CEPS-TÜSIAD conference, 6 November 1997, p.9.. Mr. Cameron is an adviser at the Central Planning Department for External Relations of the European Commission.

9- Molle, W. : The Economics of European Integration-Theory, Practice and Policy, Dartmouth, 1990, p.30.

10- Noel, E. Recent Developments in European Union-Turkey Relations, Conference paper, Istanbul, 1992.

11- This part is partially adopted from a previous publication: Kabaalioğlu, Haluk: "Completion of the Customs Union and the Accession of Turkey to the European Union", in The European Union in a Changing World, -Third ECSA World Conference, Brussels, 19-20 September 1996, A Selection of Conference Papers, European Commission, Official Publications of the EC, Luxembourg, 1998, pp.385-427.

12- Tomkins, J. and J. Twomey, "Regional Policy", in European Economic Integration, McDonald and Dearden (eds.), London: Longman, 1992, p.100.

13- Hitiris, T., European Community Economics, second edition, Harvester, 1991, p.223.

14- According to Okun, there is a trade-oft between efficiency and equality. Okun, A.; Equality and Efficiency: The Big Trade-off, Brookings, Washington D.C.,1975.

15- For a detailed analysis of Community regional policies and related questions see, Molle,W. (1990); McDonald and Deardon, (eds.), (1990); El-Agrra, A.M., The Economics of the European Community, 4th.ed. Harvester, 1994; Nielsen, J.; H. Heinrich and J. Hansen, An Economic Analysis of the EC, McGraw Hill, 1992; Artis, M.J. and N. Lee, The Economics of the EU, Oxford, 1994; Hitiris, T. (1991).

16- de Witte, B., "The Reform of the European Regional Development Fund", Common Market Law Review, 23, 1986, pp. 419-440; Lowe, P. "The Reform of the Community's Structural Funds", Common market Law Review, 25, 1988, pp. 503-521.

17- Tsoukalis, L., The New European Economy, Oxford University Press, 1993, p.245.

18- Pliponen, B.R., and M. Westman-Clement, The Agreement on the European Economic Area (EEA): A Guide to the Free Movement of Goods and Competition Rules, Oxford, 1988, pp.18-19.

19- SEC (89) 2290 tinal, 18.12 .1989$, p.9.

20- EU Tough on Ankara Under Greek Pressure- Turkey Breaks off contact with Europe" Volkskrant, 15 December 1997.

21- Papahadjopoulos, D., Greek Foreign Policy in the Post-Cold War Era : The 
Implications for the European Union, CEPS Paper No 72, Brussels, 1998.

22-The European Journal, January-February 1999

23- Stephen, M.:"European Defence-The Importance of Turkey", The European Journal, January-February, 1999.

24- Glafkos Klerides,, My Deposition, Vol.1, pp.124-126, Nicosia, 1989. The three-volume memoirs of the Greek Cypriot leader written in 1989, is exteremely illuminating. One can assume that had the current leaders of the EU Member States and officials of the Community Institutions had any idea about the events of that particular period, they would not be sitting in front of the Greek Cypriot representatives, who have no constitutional legitimacy, for what they call "accession negotiations".

25- Kabaalioğlu, H., EU and Cyprus - in view of the supra-national character of EU institutions and EU law [in Turkish] Yeditepe University Press, August, 1997, Istanbul, 415 pages.

26- For five different scenarios for the future of the EU, see L. Tindemans, Europe: Your Choice-Five Options for Tomorrow's Europe, (ed. by S.V.T.V. Serooskerken), London, 1995.

27- The Committee of Regions in which Turkish Cypriots will be represented, receives a lot of comments from many scholars. K. Middlemans seems extremely critical: "so much imprecision hangs about the Committee of Regions that it could be argued that the twelve member states simply followed an old tradition of trying out an attractive idea in a closely worded text, then retired to see what would happen. The Treaty's text offered no definition of what a region was, or how such a Committee should be chosen" (p.384). He continues, "whether or not the wilder hopes attached to regionality, either as the test case for susidiarity or as the badsis for experiments by an EU developmental state were justified is still debatable, as is the significance of that odd speculative creature, the Committee of Regions, to which Maastricht gave birth". As it is clear "the main decision-making body in which the Turkish Cypriots would be represented", according to the Commission Representative in Cyprus, actually has no status or power which could be regarded as a meaningful safeguard for Turkish Cypriots. The implication to the effect that being represented in this important "Committee" would enable the Turkish Cypriots to obtain maximum benefit from Community Funds seems also totally baseless, as pointed out by Middlemans, "where member states dictate the terms, that is the case of roughly $85 \%$ of regional aid by volume, national distictions persist, as they did when governments chose their representatives on the Committee of Regions" (p.398)..."Europe and the regions without nation states will be a complete disaster because there will not be adequate means of integrating the EU itself". What about the arguments that the Commission, which is the guardian of the Treaties, would intervene to protect the Turkish side in Cyprus, in a case the federal Government usurps the Turkish rights? The same scholar replies in his book -Orchestrating Europe- "The Commission has rarely (if ever) intervened on behalf of a region against the interest of a member state. Yet, some regions are undoubtedly exploited by their national authorities and might welcome redress, if it came in constitutionally admissable ways". Middlemans notes that "Delors pointed out that continued existence of economic and social disparities implies that thenpolitical union 
will be restricted to more favoured regions and member state capitals. But where the redistribution touches political resources the Committee of Regions is unlikely to be able to help" (p.399).

28- This is how a Minister of Foreign Affairs of Italy explains the background to the Yanya (Ioninina) Compromise: "During the time I was Italy' Minister of Foreign Affairs, the gravest tensions among the EU partners occurred when the relatively smaller nations of Austria, Finland, Sweden and at that time Norway, were in the process of joining the Union.

29- Middlemans, Orchestrating Europe-The Informal Politics of the European Union 1973 1995, London, 1995,

30-Bourlanges, J.L. "Archieving a new balance between small and large Member States", in a larger EU, can all member states be equal? Brussels, 1996, p.27

31- See, "Justice Grinding to a Halt, THE EUROPEAN, 24-30 August, 1995, p.1.

32- "Legitimacy or Efficiency: the IGC's Dilemma", in Philip Morris, p.49.

33- European Community Law, London, 1993, p.650

34- Paddy Ashtown: "How we can make Europe more relevant to voters?" in How can the EU's voters have their say?, The Philip Morris Institute, Brussels, 1995, p.17-19.

35- Proposal foer Regulation a Council (EEC) "implementing within the EEC Decision No $3 / 80$ of the EEC-Turkey Asssociation Council on the application of the social security schemes of the Member States of the EC to Turkish workers and members of their families", COM (83) 13 final, 2 February 1983. 